\title{
Comprehensive combined chemical and pharmacognostic approach in the investigation of Montenegrin flora, with emphasis on endemic species: Past performance and future potential
}

\author{
Nebojša R. Menković ${ }^{1, *}$ And VAnja M. Tadić ${ }^{1}$ \\ ${ }^{1}$ Institute for Medicinal Plants Research "Dr. Josif Pančić", Tadeuša Košćuška 1, 11000 Belgrade, Serbia \\ *Corresponding author: nmenkovic@mocbilja.rs
}

Published: December 25, 2021

Received: September 14, 2021

Accepted: December 1, 2021

Published on-line: December 20, 2021

\begin{abstract}
Herein, we have reviewed the comparative analysis relating pharmacognostic and chemical approaches in the investigation of the chosen plants from Montenegrin flora known for the constituents recognized as carriers of different biological activities. In addition, some of the mentioned extensively studied plants were with uncertain status in the systematics, as not being recognized as new species. The results of pharmacognostic studies with the thorough chemical analyses addressing the problem in positioning some of the investigated plants from Swertia, Gentiana and Gentianella genera belonging to family Gentianaceae in systematics, performed within the collaboration of two research groups from Institute for Medicinal Plants Research "Dr. Josif Pančić" and Faculty of Chemistry, the University of Belgrade under the leadership of Dr. Nebojša Menković and Prof. Dr. Slobodan Milosavljević were summarized. In addition, the complete chemical structure elucidation of sesquiterpene lactones present in Anthemis sp. as potential anti-inflammatory agents, applying the sophisticated 2D NMR techniques was reviewed. Further, the parthenolide content determination in Tanacetum larvatum revealed the possibility of the successful application of ${ }^{1} \mathrm{H}$ NMR techniques in quantification studies. The findings presented in the published literature stressed the importance of a combined chemical and pharmacognostic approach in the investigation of natural products originating from plants.
\end{abstract}

Key words: Combined pharmacognostic and chemical research; Swertia, Gentiana, Gentianella, Anthemis and Tanacetum species; oxygenated xanthones; sesquiterpene lactones, taxonomic markers; structure-activity investigation of secondary metabolites

http://dx.doi.org/10.5937/leksir2141106M

\section{INTRODUCTION}

Emerging trends in the current research and development strategies in pharmacy and medicines are prompting the interest in natural products as a source of chemical diversity for different types of medicines. Several different strategies based on chemical, pharmacognostic, and ethnopharmacological observations, resulting in consistent mapping for establishing the structure-activity relationship of drug-related chemicals, have been employed in exploring the biodiversity of the plants in the search for novel chemical structures and biological activities.

Given the numerous, naturally originated, chemically distinct molecules with significant and different biological functions, the intriguing question that might help in directing the investigation, is whether the naturally occurring, biologically active, and biosystematically important secondary metabo- lites exist in more than one particular species, recognized in traditional medicine. The second question is whether it would be of value to use unconventional and geographically limited plant sources that have never been systematically explored. In consent with such approaches, the rediscovery of known compounds recognized as carriers of the biological effects in traditionally used, well-characterized, and investigated medicinal plants, but in our investigations in endemic or in distantly related species, or characterization of the novel compounds found either in traditionally recognized sources or new ones, could represent the base for the novel systematic approach, comprising the study of the unique chemical fingerprints as the base for metabolomics investigations, as well. Further, in order to fully understand those problems associated with the complexity of correlation between the chemistry of the plants and their biological activities, one must possess the knowledge of the plants themselves, the chemical constituents in the 
plants, methods for their identification, aiming in pointing out the biochemistry pathways responsible for the certain profile of the secondary metabolites present in the species. Medicinal herbs have been remaining as the basis for the new drug discovery. According to World Health Organization, the demand for medicinal plants is US \$14 billion per year and is likely to increase to more than US $\$ 5$ trillion by 2050 . However, the efficacy of many of them has not been established, lacking in the chemical, biochemical, physical, and biological determinants important for the precise definition of their place both in herbal medicine and in systematic.

The research on the Balkans' flora at the beginning of the $20^{\text {th }}$ century (1927) revealed the presence of 6750 species, about 1750 being endemic. Afterward, a large number of new taxa have been described, and within the new species have been discovered, causing the increase of a total number of species identified, and thus endemics, as well (estimated at 7,500 species and close to 2,000 endemics). Interestingly, 3920 species are listed in the flora of Montenegro (taking into account the subspecies, the number amounts to 4140). According to the indicator of flora density (representing the number of species/area of the territory, which is 0.844 ), Montenegro takes second place in Europe (after Greece). The great complex of Montenegrin flora represents the challenge for both chemists and pharmacognostic investigators. Namely, out of 3600 species and subspecies detected on the territory of Montenegro, the total number of Balkan endemics taxa of the rank of species and subspecies is 372 (Vuksanović, 2016). The Durmitor massif has a total of about 1300 plant species, of which 122 are endemic. Prokletije has about 1400 plant species, 126 being endemic (Stevanović, 1999; Stevanović and Vasić, 1995). That was the reason that the joint research of different plant species, originated from Montenegro, had been undertaken by the Institute for Medicinal Plants Research and the research group of Professor Slobodan Milosavljevic from the Faculty of Chemistry, University of Belgrade. This review has the aim to give insight into the necessity of a combined approach to the investigation of plants, providing the detailed information on their chemistry that might be used in the proper determination of pharmacological properties, and their place in plant systematic, when it is impossible to distinguish two botanically similar species. Several secondary metabolites were chosen as the final targets for a comparative chemical survey - iridoids, xanthones, and sesquiterpene lactones being investigated most thoroughly within several plant genera-Gentiana, Gentianella, Swertia, Anthemis, and Tanacetum. Providing the chemical fingerprint of the investigated plants served as the base for not only prediction of their possible pharmacological properties, but as well might contribute to solving the dilemma existing in their chemotaxonomy. Taking into account that this review contemplated the investigations conducted in joint research of Chemical Faculty University of Belgrade and Institute for Medicinal Plants Research "Dr. Josif Pančić", the pharmacognostic and chemical investigation would point out the significance of their cooperation.

\section{PHARMACOGNOSTIC STUDIES ON MONTENEGRIN FLORA}

Professor of Natural Sciences Dr. Josif Pančić undertook the research of Montenegrin flora in the second half of XIX century, where his investigation addressed mainly its floristic elements (Pančić, 1874). Pančić reached Montenegro from Belgrade in July 1873 via Trieste and Kotor, Cetinje being the first stop. This detour was the consequence of the political and security issues in that period - namely, it was necessary to circumvent Sandžak, as part of the Ottoman Empire, located between Serbia and Montenegro. From Kotor Pančić, via Njeguš had gone to Cetinje from where he explored Lovćen (Jezerski vrh and Štirovnik). After that, he left for Durmitor, through Katunska nahija, Bjelopavlovići, Danilovgrad, and the Ostrog Monastery. Afterward, he explored the flora of Nikšić and Lukovo polje. Via Šavnik, he had arrived in Žabljak, from where he went to Durmitor, there visiting the sites on Crvena greda and the lake Crno jezero, as well as the peaks of Stouc and Sljeme. After he had visited the Morača Monastery via Tušina and Javorje, he stayed in Komovi for a short time, where he found rare and new species, of which the most significant were certainly the species: Heliosperma macrantha Pančić, Valeriana bertiscea Pančić, and Hieracium naeglianum Pančić, all having now the status in botany as "good species" (Pulević, 2006). From Komovi, he returned to Cetinje, via Morača, Zeta, and Skadasko Lake (Vir), afterward making the trip to Sutorman, and from Vir he arrived in Cetinje via the Crnojević River. From Cetinje, through Cuca and Grahovo polje, to Bijela gora, Vučji zub, and Orijen, then through Krivoši and Risan, he reached Kotor, closing the circle. Two years later, in 1875, in Belgrade, he published his famous work "Elenchus plantarum vascularum quas aestate a. 1873 in Montenegro" (Pančić, 1874), describing almost 1300 species, nine of them being new.

Having in a mind the directions of Dr. Josif Pančić investigation, the researchers from the Institute for Medicinal Plants Research "Dr. Josif Pančić" (further in the text "Institute"), followed his route, with the aim to explore the floral richness and diversity and to collect the plants (with specific attention to endemic species) (Figure 1). In order to enable the chemical characterization of the collected plant material, the tight cooperation with the research group of Prof. Slobodan Milosavljević from the Faculty of Chemistry, University of Belgrade, was established.

The investigation of Montenegrin flora by Institute's and prof. Milosavljević's research teams were undertaken on Orien, Bjelasica, Visitor, Hajla, Komovi, Prokletije, and Sinjajevina. Orjen was investigated from 2000 to 2007. The locations where the pharmacognostic research was conducted were: Kruševica, Vrbanj, Orjen sedlo, Orjen strane, Orjen vrh, Reovačka greda, Reovci, Zubački kabao, Jarčeva tvrđa, Ubli, Grab, Podstirovnik. The sub-Mediterranean and Mediterranean areas were explored, as well, from Herceg Novi to Kamen and Kruševica, then Luštica, and part from Risan to Crkvica. The mountain Bjelasica was explored in the period from 1998 to 2006, on localities: Svinjača, Mušovića rijeka, Jezerine, Klisura, katuni Vranjak, Potoci, Slađevac, Klisura, Melaja then Troglava, Ogorela glava and Zekova Glava, Pešića lake and wider surroundings, then Ocka, Šiško Lake, Kurikuće, Otaševa lica. In the period from 2001 to 2007, the following sites at Visitor were explored: Pepići, Pepićka reka, Zaparenik, Tomov Laz, Jagnjičar, Visitor Lake, Mramorje, Marašov katun, Kachuber, Valje, Velji vrh, Bandera vrh, Kupušnjak, as well as a number of unnamed localities especially on the slopes of the mountain. Hajla and Ahmica were investigated during the period of 1998 to 2007, especially Dramandol, then the area towards Ahmica from Cafa Hajla, over Ujka's karst to the slopes and the top of Ahmica. The Čakor Mountain is located in the Northeast of Montenegro and geographically belongs to Prokletije. Representing the natural border between Adriatic and Black Sea basins, it is rich in flora. The investigation of this area was performed during 1998-2006 (Figure 2). The Čakor Mountain stretches north-south, while to the east it is open through the Rugova gorge towards Metohija, and to the west, towards the valley of the river Lim, it descends through the large amphitheater of the village Velika. In the south, it starts from the Dio saddle, then across the Čakor and Lijepi do passes spread to the north to Ćafa, the saddle between Mokra 


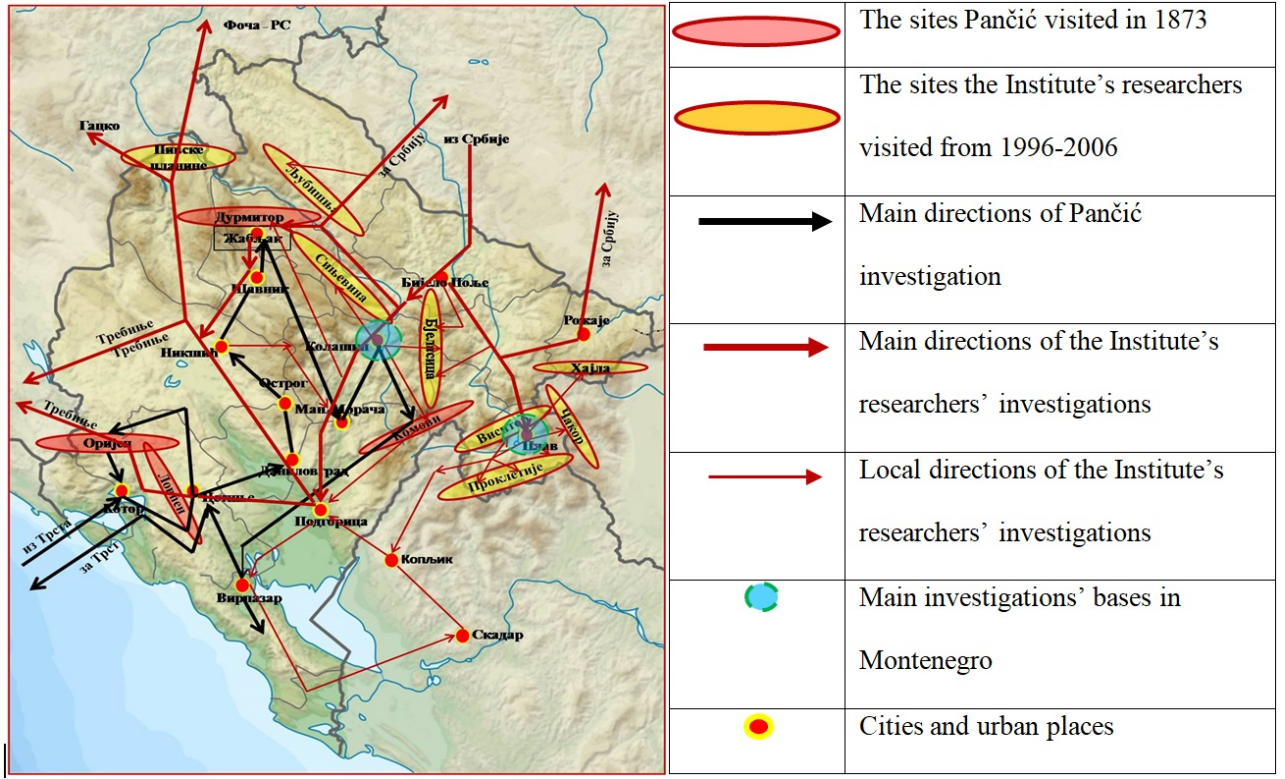

Fig. 1. A comparative presentation of the research routes of Dr. Josif Pančić undertaken in 1873 and research teams from Institute for Medicinal Plants Research “Dr. Josif Pančić" and Faculty of Chemistry, University of Belgrade during 1999-2007 in Montenegro

Table 1. The plant species present at the research areas of Montenegro with the most prominent pharmacognosy, chemical, and economic significance

\begin{tabular}{rlll}
\hline$\#$ & Specie & Family & Drug \\
\hline 1 & Abies alba Mill. & Pinaceae & Raw fir leafs; cone; bark \\
2 & Achillea millefolium L & Asteraceae & Herbaceous above-ground \\
3 & Agrimonia eupatoria L. & Rosaceae & Herbaceous above-ground \\
4 & Alchemilla hybrida Mill. & Rossaceae & Herbaceous above-ground \\
5 & Alchemilla vulgaris L. & Rossaceae & Herbaceous above-ground \\
6 & Arctostaphyllos uva ursi (L.) Spreng. (Figure 5 ) & Ericacae & Leaf \\
7 & Betula alba L. & Betulaceae & Bark and leaf \\
8 & Epilobium angustifolium L. & Oenotheraceae & Herbaceous above-ground part or only leaf \\
9 & Fragaria vesca L. & Rosaceae & Leaf \\
10 & Gentiana asclepiadea L. & Gentianaceae & Root \\
11 & Hypericum perforatum L. & Hypericaceae & Herbaceous above-ground part \\
12 & Juniperus communis L. & Cupressaceae & Fruit, wood and essential oils \\
13 & Orchis morio L. & Orchidaceae & Tuber \\
14 & Origanum vulgare L. & Lamiaceae & Tips of flowering branches and essential oils \\
15 & Pinus mhugo Turra. & Pinaceae & Tips of branches and essential oils \\
16 & Polygonum bistorta L. & Polygonaceae & Rhizome \\
17 & Primula elatior L. & Primulaceae & Root and flower \\
18 & Rosa canina L. & Rosaceae & Fruit \\
19 & Salix purpurea L. & Salicaceae & Bark \\
20 & Taraxacum officinale Weber & Asteraceae & Root, rarely entire plant with root \\
21 & Urtica dioica L. & Urticaceae & Leaf and root and aboveground part \\
22 & Vaccinium myrtillus L. (Figure 4$)$ & Ericacae & Fruit, leaf and sprouts \\
23 & Veratrum album L. & Liliaceae & Rhizome with roots \\
24 & Verbascum thapsus L. & Liliaceae & Flower \\
25 & Viola tricoloris L. & Violaceae & Above-ground part \\
\hline & & &
\end{tabular}




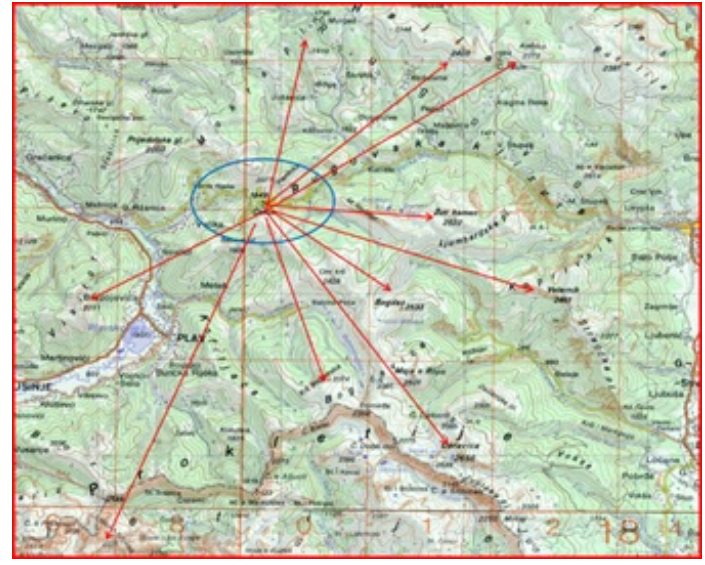

Fig. 2. The main routes at the Cakor Mountain investigated by Institute's and Faculty of Chemistry research teams during 19982006

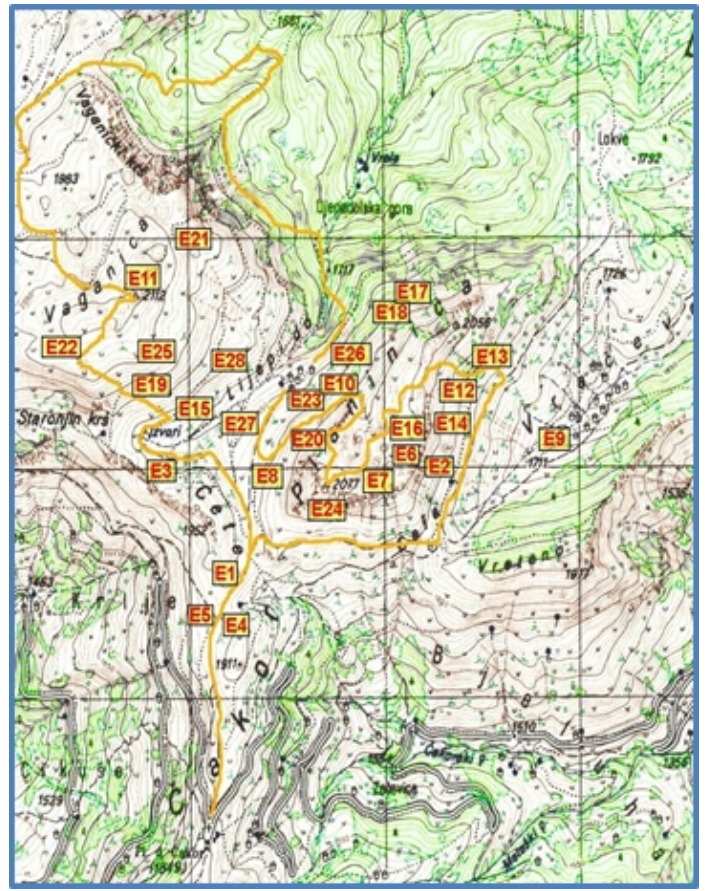

Fig. 3. The cartographic representation of the endemic species identified in investigated areas of the Mountain Čakor

and Vaganica. The mountain Čakor consists of the mountains Vaganica (the highest peak $2112 \mathrm{~m}$ ), Planinica (2077 $\mathrm{m}$ and $2054 \mathrm{~m})$, Vreteno (1961 m), and Đevojački Vrh (2057 m), interconnected bypasses and extending in a line in a north-south direction. Between Đevojački Krš, Planinica and Vreten, there is the Čakor pass $(1849 \mathrm{~m}$, being at the same time the lowest point of mountain). Lijepi do is located between Vaganica and Planinica, beginning at an altitude of $1915 \mathrm{~m}$ and gently descends towards Vaganička gora $(1700 \mathrm{~m})$ and Vraćevo. Lijepi do, with the northern slopes of Planinica and the eastern sides of Vaganica, as well as the tops of Vaganička gora represent the floristic center of the mountain region Čakor. Due to its geographical position, relief forms, rich and diverse flora, barrenness, and wilderness, the mountainous region of Čakor represent one of the most beautiful Montenegrin landscapes. In the foreground, west of Vaganica, the Visitor massif (2211 $\mathrm{m})$ with Greben and Zeletina continues towards Jerinja glava and Bjelasica, in the background covered by gigantic Komovi. The northeastern part in the foreground consists of Cmiljevica and the mighty Hajla (2403 m), and at the end, the Golija and
Kopaonik massifs ( $2017 \mathrm{~m}$ ) can be seen in the distance.

During the research 1998-2006, the joint team of Institute and Prof. Milosavljević, evaluated the diversity of the Montenegrin flora, with the specific attention to those species characterized by prominent pharmacognosy and chemical significance (Menković et al., 2011; Tasić et al., 2009; Tešević et al., 2007; Trifunović et al., 2006; Zdunić, 2012; Zdunić et al., 2011). In addition, it was important to point out the species that could be exploited for economic purposes rationally and without endangering their survival due to their abundant presence in nature (Table 1). Within the plants detected at the investigated locations, the presence of the endemic species was confirmed and listed in Table 2 and Figure 3. The presented findings were in accordance with previously performed research and detected species (Braun-Blanquet, 1964; Josifović, 1975; Lakušić, 1968; 1971; 1974; 1990; Lakušić and Milojević, 1972; Lakušić et al., 1985; Lukić, 1985; Milojević et al., 1974; Pulević, 2005; Schilcher et al., 2007; Šilić, 1983; 1984; Tucakov et al., 1974).

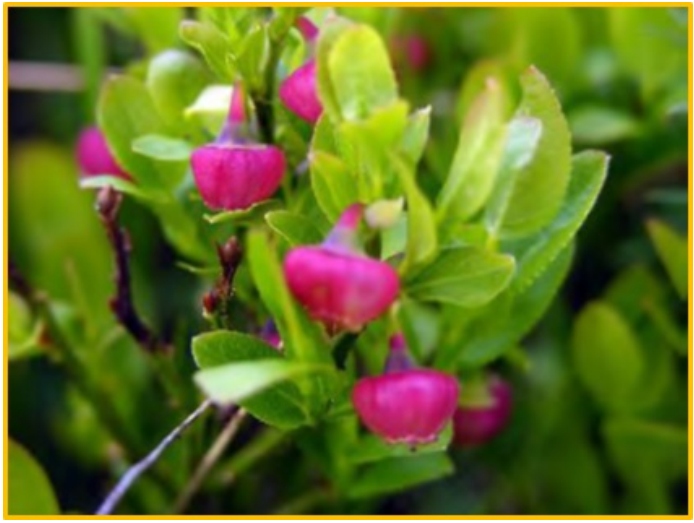

Fig. 4. Vaccinium myrtillus L. Ericacae (Photo by Jeremić Miroslav)

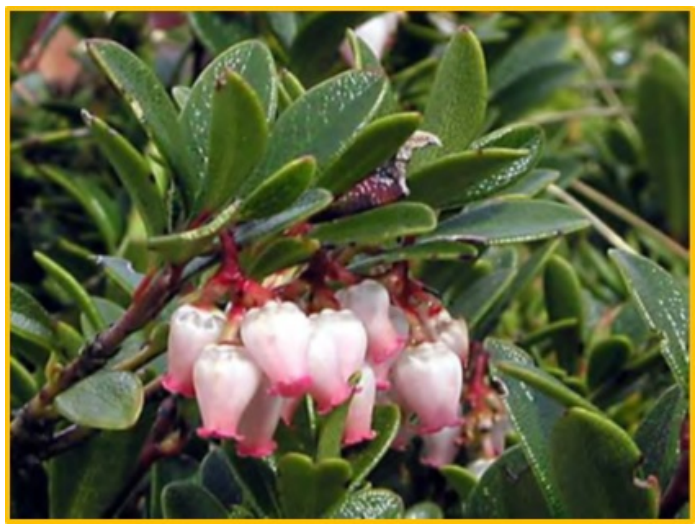

Fig. 5. Arctostaphyllos uva ursi (L.) Spreng., Ericacae (Photo by Jeremić Miroslav, taken at the peak Planinice $(2077 \mathrm{~m})$, the Čakor Mountain)

Among numerous medicinal plants disclosed during the research conducted on mountains Prokletije and Komovi, it was revealed that $V$. myrtillus (Figure 4) was widespread throughout Montenegrin meadows and pastures, whose aerial parts, Vaccinii herba and Vaccinii fructus are official in European Pharmacopeia (Milojević et al., 1974). Apart from this plant, A. uva ursi (Figure 5) represent one of the most economically important species in Montenegrin flora, distributed in significant abundancy on Prokletije, Komovi, and Bjelasica (Gorunović and Lukić, 2001; Lakušić and Milojević, 1972).

The conducted studies were focused on the plant species, either those having the application in pharmaceutical, chemical, 
Table 2. Identified endemic species at the investigated area of the mountains Čakor, Bjelasica, Prokletije and Durmitor

\begin{tabular}{|c|c|c|c|c|c|}
\hline Code & Species & Family & Code & Species & Family \\
\hline E1 & Acer heldreichii Orph. & Aceraceae & E16 & Pancicia serbica Vis. & Umbelliferae \\
\hline E2 & Achillea abrotanoides Vis. & Asteraceae & E17 & Pedicularis brachyodonta Schloss. Et Vukot. & Scrophulariaceae \\
\hline E3 & Achillea lingulata W. et $\mathrm{K}$. & Asteraceae & E18 & Pinus peuce Grisebach & Pinaceae \\
\hline $\mathrm{E} 4$ & Aconitum vulparia Reich. $^{\dagger}$ & Ranunculaceae & E19 & Plantago reniformis G. Beck. & Plantaginaceae \\
\hline E5 & Aconitum penteri Hay. & Ranunculaceae & E20 & Potentilla montenegrina Pant. & Rosaceae \\
\hline E7 & Anthyllis jacquini Kern & Fabaceae & E21 & Ranunculus scutatus Waldst. \& Kit & Ranunculaceae \\
\hline E8 & Cerastium dinaricum Beck et Szysz. & Caryophyllaceae & E22 & Sempervivum kosaninii Praeger & Crassulaceae \\
\hline E10 & Euphorbia myrsinites L. & Euphorbiaceae & E23 & Tanacetum larvatum (Pant.) Hayek & Asteraceae \\
\hline E11 & Geum bulgaricum Pančić & Rosaceae & E24 & Valeriana pancicii Halacsy \& Bald & Valerianaceae \\
\hline E12 & Lilium albanicum Gris & Liliaceae & E25 & Viola nicolai Pant. & Violaceae \\
\hline E13 & Onobrychis scardica Griseb. & Fabaceae & E26 & Wulfenia blecicii Lakušić & Scrophulariaceae \\
\hline E14 & Oxytropis dinarica Murb. & Fabaceae & E27 & Gentianella bulgarica (Velen.) Holub & Gentianaceae \\
\hline E15 & Oxytropis halleri Koch & Fabaceae & E28 & Gentianella crispata (Vis.) Holub & Gentianaceae \\
\hline
\end{tabular}

${ }^{\dagger}$ Aconitum vulparia Reich. ssp. pantoscekiaum (Deg.\& Bolu) Hay.

food, and cosmetic industries, at the same time known for their application in scientific and traditional medicine (official domestic and foreign pharmacopoeias) or being rare, endemic or specific for the investigated area (a potential source of new medicinal material, at the same time, providing the opportunity for comprehensive pharmacognostic and chemical research). Based on the above-mentioned requests, but being aware of the growing trend for research and exploitation of medicinal plants, this review was oriented mainly to the successfully applied pharmacognostic and chemistry approach in the research of several species, known as a rich source of either xanthones, or sesquiterpene lactones (Aljančić et al., 2008; Šavikin et al., 2015; Godjevac et al., 2004; Gođevac et al., 2006a;b; Janković et al., 2005; 2009; 2011; Krstić et al., 2004; Menković et al., 2002; 2014; Milosavljević et al., 1998; Šavikin-Fodulović et al., 2003; Šavikin et al., 2010; Tešević et al., 2007; Trifunović et al., 2006; Zdunić, 2012; Zdunić et al., 2011). Namely, the constant development of analytic methods, along with intensified pharmacological and clinical researches, has been opening the interesting field of quantitative structure-activity relationship (QSAR), stressing the importance of structure elucidation of isolated natural compounds from plants.

Xanthones, the secondary metabolites found in some higher plants, fungi, and lichens, due to their high taxonomic values aroused the noteworthy interest in order to research their pharmacological properties. In 1977, xanthone glycosides were described by Hostettmann and Wagner as an extensive group of natural xanthones. Based on the literature, about 650 xanthones are known from natural sources, the majority occurring in two plant families, Gentianaceae and Hypericaceae (Hostettmann and Wagner, 1977; Niaz and Khan, 2020). Iridoids represent one of the most important secondary metabolites in Gentianaceae, while Asteraceae is the family known for abundance in sesquiterpene lactones. With $>1500$ known members, the iridoids have been frequently investigated in plant chemosystematics studies, beginning with Dahlgren in the 1980s (Dahlgren, 1980). Apart from divergent findings in insects, the main distribution of iridoids is in the subclass Asteridae of the flowering plant family Gentianaceae, which is known for their presence in quite significant quantity. In addition, they are known to possess a variety of biological activities. The genus Gentiana comprises approximately 400 species. Many species have a wide range of pharmacological activities and have been used therapeutically for thousands of years. This review presents updated information concerning the recent progress on chemical and pharmacognostic analysis of some of the species belonging to Gentianaceae. Detailed and comprehensive data illustrate the numerous newly discovered monoterpene derivatives (xanthones and iridoids) and confirm the presence of the known ones responsible for therapeutic uses, stressing the existing structure-activity relationship.

Sesquiterpene lactones (SLs) represent one of the biggest groups of secondary metabolites, one of the largest biogenetically homogenous groups of natural products known. Currently, the Dictionary of Natural Products holds over 11000 entries on sesquiterpene lactones. They represent the class of terpenoids with more than 30 skeleton subtypes and several substitutional features, known not only as carriers of different biological activities (antitumor, allergenic, phytotoxic, antimicrobial, insecticidal, etc.) but as well as chemotaxonomic markers. Namely, in the early 1960s, major emphasis was on the use of SLs as taxonomic markers in systematic biochemical studies (Djordjević et al., 2004; Milosavljević et al., 1999a; 1998; Tadić et al., 2009). Although the species-rich family of Asteraceae is known for significant SLs content, this group of natural compounds might be found in some other plant families, like Lauraceae, Apiaceae, Burseraceae, and Magnoliaceae, as well as in some fungi. Here, Anthemis sp. and Tanacetum sp. will be presented as the representatives, taking into consideration that those genera were thoroughly investigated regarding their chemical composition, with the connection to taxonomic significance (Aljančić et al., 2010; 2001; Bulatović et al., 1997a; 2006; 1997b; Tadić et al., 2010; Vajs et al., 1999; 2000).

\section{THE COMPARATIVE STUDIES}

\subsection{The comparative study on Swertia perennis and S. punc- tata}

In the flora of Europe, there is only one species of the genus Swertia, S. perennis, which belongs to the Pentamera section, the Alteae subsection, and the Perennis series. S. perennis is an arcto-tertiary relict of mountain flora. The Perennis series includes two more vicarious species: $S$. iberica (Caucasian floral element) and S. obtusa, which is a widespread Asian species. Although only S. perennis is officially recognized in European Flora. Tan and Vladimirov (2001) claimed recently that S. punctata growing on the moistly terrains of the Western Stara Planina mountain, situated between Bulgaria and Serbia, represented the well and precisely defined plant species differing from S. perennis occurring in Rila, Vitosha and Pirin mountains (Bulgaria), but missing in Serbia. S. punctata is also described by Jovanović-Dunjić (1973) as the only species of 
the genus occurring in Serbia. According to Tutin et al. (1972), the existence of the species S. punctata, S. alpestris and S. obtusa outside the species $S$. perennis has been denied, with the explanation that the described differences in morphological characteristics (leaf arrangement, cup shape, flower color, hair length on nectary, etc.) are not sufficient for differentiation at the subspecies level, given that the species appear sporadically throughout Europe. They also gave the data that the populations of S. perennis and S. punctata in the Balkans differentiated. In their work, the authors presented the diagnostic characteristics of each species individually.

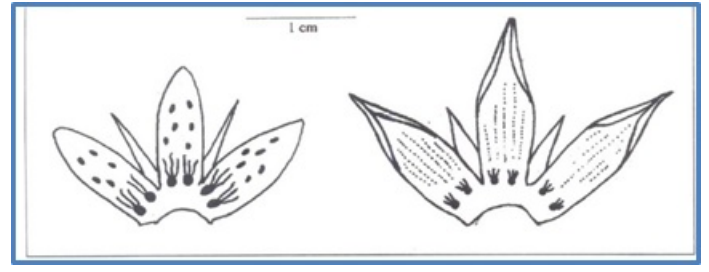

Fig. 6. Dissected corollas of S. punctata (left) and S. perennis (right)

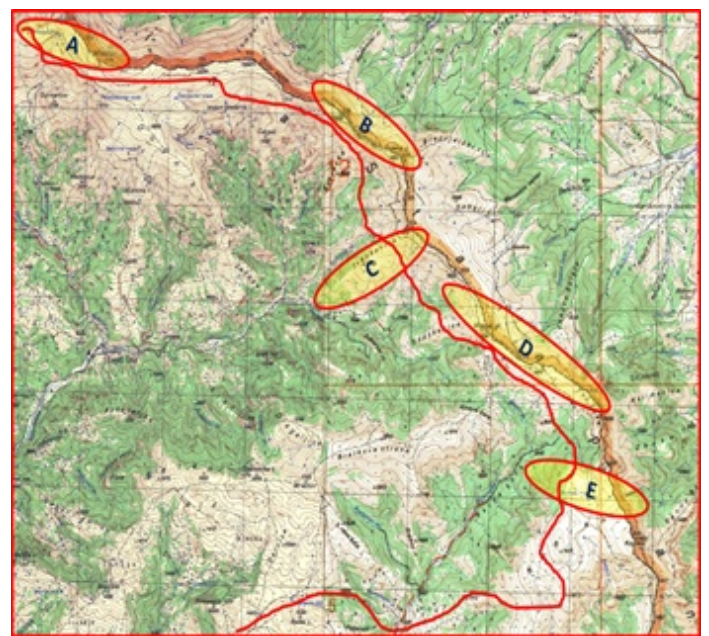

Fig. 7. Distribution of S. punctata on Stara Planina: Tri kladenca (Midžor, A.), Golema Čuka (B), Ivankovica (C), Vražja Čuka (D), Tri Kladenca - Kopren (E)

To confirm this finding, a thorough investigation of the chemical properties of both species was carried out, giving a new perspective in order to separate these two species within Swertia genera (Stevanović, 1999). In the review, the comparison of the botanical (Figure 6, Table 3), but as well as the chemical characteristics of the two species, S. punctata and S. perennis, performed by the prof. Milosavljevic and Menkovic's group of researchers will be presented (Menković et al., 2002).

Figures 7 and 8 presents the distribution of the species S. punctata L., Gentiananceae with common name "picobojka on Stara Planina", confirmed by pharmagnostic investigations undertaken within several projects financed by Ministry of Education, Technology and Technological Development, Serbia. The red line (Figure 7) represented the research route of Dr. Josip Pančić from 1880, performed on Stara Planina, in the direction of Rosomač-Ržana-Vrtop-Kopren-Tri čuke-Vražja Glava, Ivankovica-Krvave Bare and Toplo Do, when the species $S$. punctata was first described. The results were published as addition to the Flora of the Principality of Serbia (1973) (Pančić, 1874).

After thorough extraction of the plant material collected ( $G$. punctata and G. perennis at Stara planina- Kopren and Žugića bare - Durmitor, respectively), the isolated and purified compounds (Figure 9) were subjected to chemical analysis, and

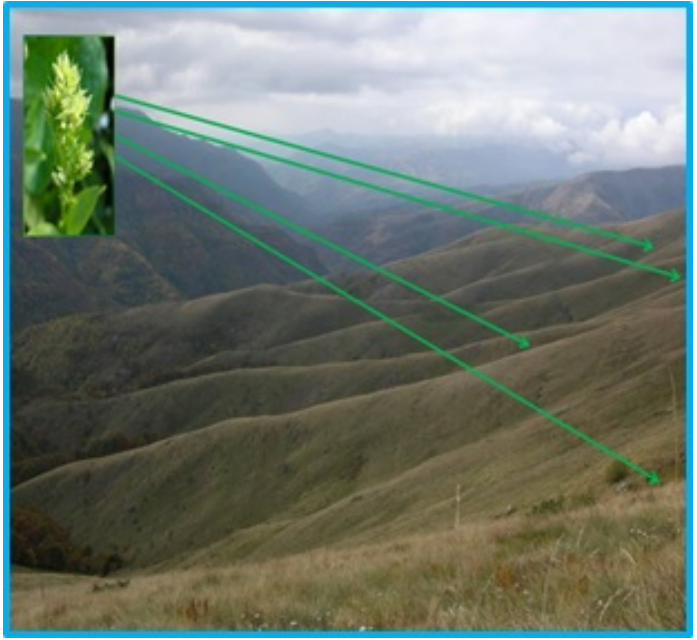

Fig. 8. View from Ivankovica $(1780 \mathrm{~m}$ ) towards Topli do (on the left side of the massif of Bratkova strana, $1980 \mathrm{~m}$ ), where the most abundant areal of $S$. punctata was localized

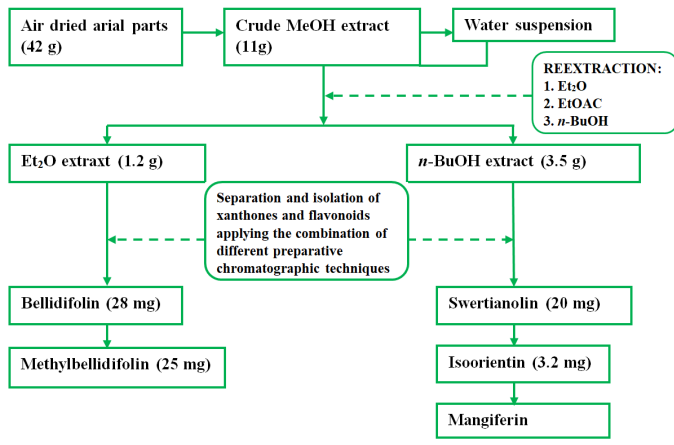

Fig. 9. Scheme of extraction procedure of the aerial part of S. punctata

their structure were elucidated, applying ${ }^{1} \mathrm{H}$ and ${ }^{13} \mathrm{C}$ NMR techniques, as well as LC-MS methodology, revealing, besides the already known (Figure 10), the presence of two new components, until now unknown in the plant kingdom (Figure 11) (Menković et al., 2002). The comparative review of pharmacognostic and chemical characteristics of $S$. punctata and $S$. perenis (Tables 4 and 5) revealed the differences that might be considered as the starting point in the distinct separation of these two species within Swertia genera.

The complete chemical composition of methanol extract of $S$. punctatae folium was achieved by applying the LC-MS analysis (Figure 12). Sample preparation comprised the dissolution of extract in methanol $(\mathrm{c}=10 \mathrm{mg} / \mathrm{mL})$ prior HPLC analysis, all the samples being filtered through a Teflon Millipore filter type HV $0.45 \mu \mathrm{m}$. In all analyzed samples the quantification of secoiridoid, flavonoid, and xanthone complex, present in Gentianaceae, was carried out. The analysis was conducted on Agilent MSD TOF coupled with Agilent 1200 series RR liquid chromatograph, equipped with column LiChrospher $100 \mathrm{RP}$ $18 \mathrm{e}, 150 \times 4.0 \mathrm{~mm}$ i.d., $(5.0 \mu \mathrm{m})$. Injection volume was always $5 \mu \mathrm{l}$ of prepared extracts, and the flow rate was $0.995 \mathrm{~mL} / \mathrm{min}$. Mobile phases were: A - water (with $0.2 \% \mathrm{HCOOH}$ ), B $\mathrm{MeCN}$, and the acceptable separations of the compounds were achieved using gradient elution (98-90\% A (0-5 min); isocratic $90 \%$ A (13 min); $90-85 \%$ A (18-20 min); isocratic $85 \%$ A (for $5 \mathrm{~min}), 85-70 \% \mathrm{~A}(25-30), 70-30 \% \mathrm{~A}$ (30-40 min), isocratic 30 $\%$ A for $10 \mathrm{~min}, 30-98 \%$ A (50-51 min), isocratic $98 \%$ A for 4 min. MSD conditions were as follows: drying gas $\left(\mathrm{N}_{2}\right)$ flow $12 \mathrm{~L} / \mathrm{min}$; nebulizer pressure $45 \mathrm{psig}$; drying gas temperature $350{ }^{\circ} \mathrm{C}$; capillary voltage, $4000 \mathrm{~V}$; fragmentor voltage, $140 \mathrm{~V}$; 
Table 3. Main differences between S. punctata and S. perennis

\begin{tabular}{lll}
\hline Characters & Swetria punctata & Swetria perennis \\
\hline Stem height & $20-65 \mathrm{~cm}$ & $15-45 \mathrm{~cm}$ \\
Stem diameter at base & $(2.5-) 3-7 \mathrm{~mm}$ & $1.0-2.5(-3.5) \mathrm{mm}$ \\
Stem colour & green & greenish-purple, rarely green \\
Number of flowers/inflorescences & $(15-) 30-65(-101)$ & $5-15(-24)$ \\
Corolla colour & greenish-yellow with blackish-violet dots & bluish- violet \\
Petal position at anthesis & erect-patent to almost erect & patent \\
Petal shape & oblong-lanceolate to linear, obtuse at apex; margin not enrolled & lanceolate to linear \\
Sepal/petal ratio & $2 / 3$ or more than $2 / 3$ of petals & $1 / 2$ to $2 / 3$ \\
Length of fimbnae & $3-5$ times diam. of nectary & $1-3$ times diam. of nectary \\
Balkan distribution & Carpathians, Western Stara Planina Mt, Kosovo & Carpathians, Rila, Pirin and Vitosha Mts
\end{tabular}<smiles></smiles>

1h: $\mathbf{R}=\mathbf{R}_{\mathbf{2}}=\mathbf{R}_{\mathbf{3}}=\mathbf{H}, \mathbf{R}_{\mathbf{1}}=\mathbf{C H}_{3}$ $2 k: \mathbf{R}=\mathbf{R}_{1}=\mathbf{R}_{3}=\mathbf{H}, \mathbf{R}_{2}=\mathrm{CH}_{3}$ $3 k: \mathbf{R}=\mathbf{R}_{3}=\mathbf{H}, \mathbf{R}_{1}=\mathbf{R}_{2}=\mathbf{C H}_{3}$ 4k: $\mathbf{R}=\mathbf{G l c}^{6}-\mathrm{Xyl}, \mathbf{R}_{1}=\mathbf{R}_{3}=\mathbf{H}, \mathbf{R}_{2}=\mathbf{C H}_{3}$ $5 h, k: \quad R=\mathbf{R}_{2}=\mathbf{H}, \mathbf{R}_{1}=\mathbf{C H}_{3}, \mathbf{R}_{3}=\mathbf{G l c}$<smiles>[R20]Oc1cc([R20])c2c(=O)c3c(O)c([R20])ccc3oc2c1</smiles>

6k: $\mathbf{R}=\mathbf{R}_{1}=\mathbf{H}, \mathbf{R}_{2}=\mathrm{CH}_{3}$ $7 \mathbf{k}: \mathbf{R}=\mathbf{H}, \mathbf{R}_{1}=\mathbf{R}_{2}=\mathbf{C H}_{3}$ 8k: $\mathbf{R}=\mathbf{G l c}^{6}-\mathbf{G l c}, \mathbf{R}_{1}=\mathbf{R}_{2}=\mathbf{C H}_{3}$ 9k: $\mathbf{R}=\mathbf{G l c}, \mathbf{R}_{1}=\mathbf{R}_{\mathbf{2}}=\mathbf{C H}_{3}$<smiles>O=c1cc(-c2ccc(O)c(O)c2)oc2cc(O)c(Cl)c(O)c12</smiles>

Fig. 10. The distribution of identified compounds in aerial (h) and underground part $(\mathrm{k})$ in $S$. perennis extracts (1, bellidifolin; $\mathbf{2}$, isobellidifolin; 3, methylbellidifolin (swerchirin); 4, isobellidifolin-1-Oprimveroside (new compound); 5 , bellidifolin-8-O-glucoside (swertianolin); 6, isoswertianin; 7, methylswertianin; 8, methylswertianin-1$O$-gentiobioside (new compound); 9, norswertianin-1-O-glucoside; 10, mangiferin; 11, isoorientin)

skimmer, $60 \mathrm{~V}$; Oct RF voltage $250 \mathrm{~V}$; positive mode, mass range $m / z$ 100-2500; 10,000 transients/scan.

As reviewed by Pant et al. (2000) xanthones bellidifolin, metilbelidifolin, methylswertianin, and mangiferin exhibited various biological activities such as: hypoglycemic, hepatoprotective, and anti-inflammatory, whereas methylswertianin exhibited antituberculous and antioxidant activities, as well. This makes S. punctata attractive as a source of medicinal raw material, but since its population is scarce and endangered, as reported recently in the Red Book of Serbian Flora (Stevanović, 1999) our efforts are now concentrated on finding out an alternative way for biomass production.

Based on the previously published work of Tan and Vladimirov (2001), it is suggested that S. punctata was well and precisely-defined plant species differing from $S$. perennis. In our work, the thorough chemical analysis of $S$. punctata (Table 6) revealed the presence of two new xanthone derivatives, namely 1-O-genciobioside of methyisogentiakochianin (rare 1,3,7,8-substitution, 1-O-gentiobiosyl3,7-dimethoxy-8-hydroxyxanthone) and 1-O-primverosidyl isobelidifoline (1,3,5,8-substitution, 1-O-primeverosyl-3,8dihydroxy-5-methoxyxanthone), isolated from the root of this plant for the first time (Menković et al., 2002). The findings that G. punctata represents species different from S. perennis<smiles>CCCOc1cc(O)cc2oc3c(OC)ccc(O)c3c(=O)c12</smiles>

1-O-gentiobiosyl methylisogentiakochainin

1-O-primverosyl isobellidifolin

Fig. 11. New compounds isolated from S. punctata (not present in $S$. perennis)

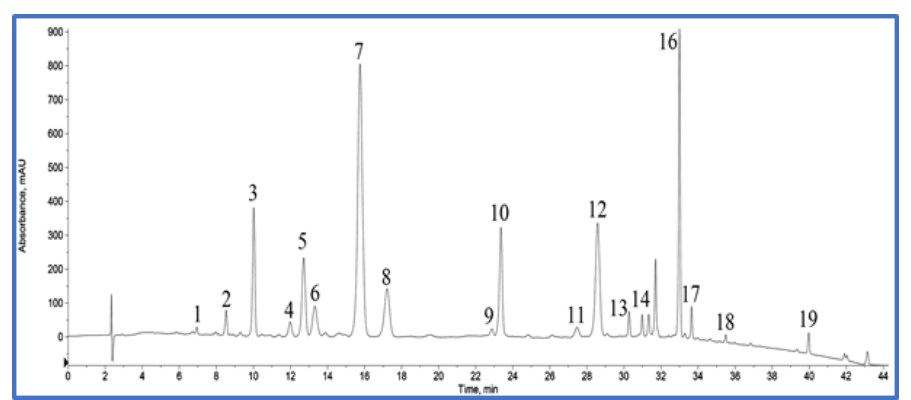

Fig. 12. Fingerprint of $S$. punctata folium $\mathrm{MeOH}$ extract analysed by LC-MS; 1, eustomorussid; 2, secologanosid; 3, loganic acid; 4, septemfidosid; 5, swertiamarin; 6, homomangiferin; 7, gentiopicrin; 8, swerosid; 9, isosapoarin; 10, mangiferin; 11, isoorientin-2"-Oglucoside; 12, isoorientin; $\mathbf{1 3}$, swertisin; 14, isovitexin; 15, swertianolin 16, swerchirin (methylbellidifolin); 17, not identified; 18, demethylbellidifolin; 19, bellidifolin

(Table 7) is of importance for systematic genera Gentiana. In addition, as the only areal of its distribution in the Balkans, further speculation is that it likely represents the stenoendemic.

\subsection{The comparative study on Gentiana kochiana and G. dinarica}

G. kochiana and G. dinarica were collected on Čakor and Prokletije, respectively. The chemical profiling regarding these two species of Gentiana genera published by Balijagić et al. (2011), revealed the significant differences between them, which had been reviewed herein (Tables 8-12; Figures 13-17). Interestingly, the aerial part of $G$. dinarica contained secoiridoids and flavonoid C-glycosides (Tables 11,12; Figure 14), while xanthone ingredients were absent, while G. kochiana was rich in iridoids and xanthones (Table 10; Figure 13). Nevertheless, the root of $G$. dinarica contained xanthones and flavonoids, isoorientin, and its derivatives, which were present in the aerial parts, as well (Table 12). In the root, a significant amount of amarogentin was found. Worth noting is that xanthone constituents were not present in the form of aglycones. 
Table 4. Swertia punctata botanical data

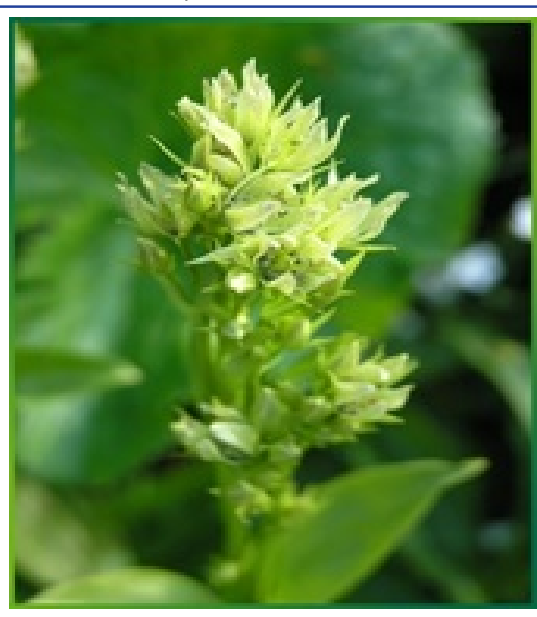

Swertia punctata Baumg.- common name: pikobojka

General distribution

Central Balkans

Floral element

Central Balkan mountain endemic

\section{Habitat}

Distributed in the range from 1500 to $2000 \mathrm{~m}$ above sea level in the zone of subalpine peat pastures and meadows and mountain ores, mainly on silicate and serpentine.

\section{Distribution in the Central Balkans}

Serbia - Stara Planina

Macedonia - Korab (Kula e Ziberit 1700 to $2400 \mathrm{~m}$ )

Bulgaria - Balkans (parts towards Serbia), Vitosha

\section{Taxonomic status}

Section: Pentamere

Swertia punctata Baumg.

From the root were isolated norswertianin-1-O-primveroside, norswertianin-8-O-primveroside, gentioside and amarogentin, as pharmacologically active constituents (Table 11; Figures 14 and 15) (Krstić-Milošević, 2008).

The bitter principles (secoiridoids) (Figure 15), the usual constituents of the genus, stimulate the secretion of gastric juices and bile, thus improving the appetite and digestion. In addition, they also exhibit other biological activities. Namely, sweroside is antihepatitic drug, and swertiamarin and sweroside inhibit the growth of Bacillus cereus, B. subtilis, Citrobacter freundii and Escherichia coli. While swertiamarin was also active against Proteus mirabilis and Serratia marcescens, sweroside inhibited the growth of Staphylococcus epidermidis. The recent investigation revealed that secoiridoids sweroside and swertiamarine possess significant general toxicity in the brine shrimp lethality test (Krstić-Milošević, 2008). Gentiopricrin has shown spasmolytic activity, in a concentration-dependent manner, the spontaneous contractions of isolated guinea-pig ileum. Contractions induced by histamine, acetylcholine, $\mathrm{BaCl}_{2}$, and $\mathrm{KCl}$ on the ileum were also significantly blocked by this monoterpene glycoside, which suggests that interference with calcium influx into the smooth muscle cells might occur (Tovilović-Kovačevicć et al., 2020). Recent studies have confirmed the radioprotective effect of infusions of the root of the G. dinarica, as well as individual xanthone components, such as norswertianin-1-O-primveroside and norswertianin-8$O$-primveroside, a new compound isolated from the root of $G$. dinarica. In addition, the significant antioxidant activity of iso-
Table 5. Swertia perennis botanical data

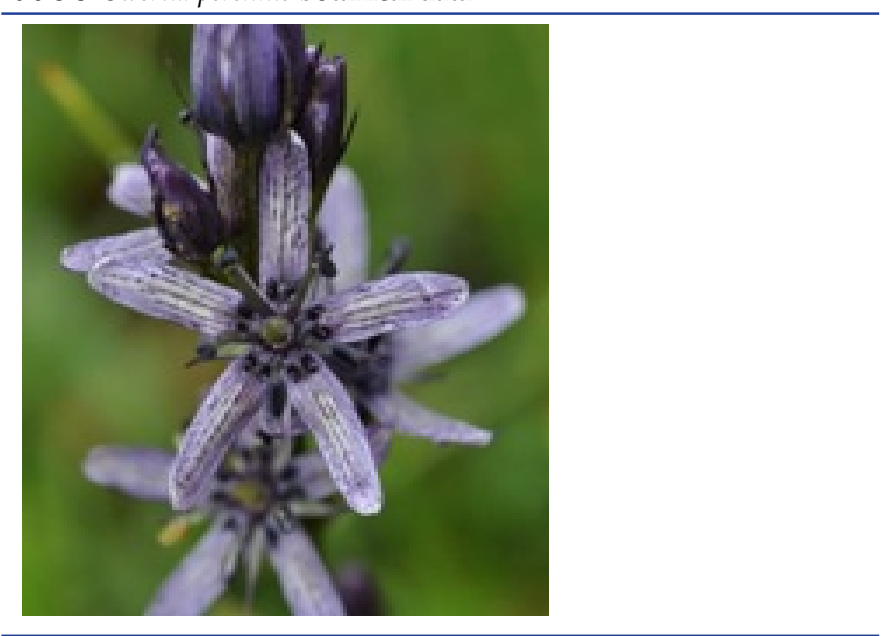

Swertia perennis L. - common name: plava pikobojka

\section{General distribution}

Alps, Northern Europe, North America, Balkan, Apennine and Iberian Peninsula, Carpathians, Asia Minor

\section{Floral element}

Boreal-Subatlantic (European)

Glacial relic

\section{Habitat}

Distribution in the range from 1000 to $2000 \mathrm{~m}$ above sea level in the zone of mountain subalpine peat bog, wet raisins, but also on brown rocky and wet runkers.

\section{Distribution in the Central Balkans}

Serbia - not found

Macedonia - not found

Bulgaria - Vitosha, Rila, Pirin

Montenegro - Žugića Bare (Žabljak)

Taxonomic status

Section: Pentamere

Swertia perennis L.

lated compounds was established, with the most prominent being norswertianin and norswertianin-1-O-primveroside. The chemical analysis of G. kochiana aerial parts extracts revealed a significant amount of xanthone aglycones gentiakochianin, gentiacaulein and decussatin, while in root extract gentiakochianin and decussatin were not detected (Table 10; Figure 13). Xanthone $O$-glycosides, gentiacaulein-1$O$-primveroside, gentiacaulein-1-O-glucoside, decussatin-1$\mathrm{O}$-primveroside and gentiakochianin-7-O-primvroside were present both in the aerial parts and roots. The most dominant xanthone $O$-heteroside both in the aerial parts and roots is gentiacaulein-1-O-primveroside. From aerial parts isolated gentiakochianin, gentiacaulein and their glycosides 1-O-primveroside and 1-O-glucoside, respectively, were pharmacologically active.

In traditional medicine, G. kochiana has been used as antipyretic, spasmolytic, immunostimulant, and gastrostimulant (amara pura). The neuropharmacological effects of diethylether extract of G. kochiana and the isolated xanthones gentiacaulein and gentiakochianin on CNS activity in rodents (Tomić et al., 2005) comprised the inhibition of monoaminoxidase (MAO) A and $\mathrm{MAO} \mathrm{B}$, thus indicating some antidepressant therapeutic potential of the tested substances. In a pharmacological study involving antiglioma action of xanthones from G. kochiana, gentiacaulein and gentiakochianin were shown to be active 


\section{$1,3,5,8$ - substitution}<smiles>[R]c1cc([R])c2c(=O)c3c([R])ccc([R3])c3oc2c1</smiles>

\section{$1,3,5,8$ - substitution}<smiles>[R2]c1cc([R])c2c(=O)c3c([R3])ccc([R3])c3oc2c1</smiles>

1 Bellidifolin

$\left(\mathrm{R}_{1}=\mathrm{R}_{3}=\mathrm{R}_{4}=\mathrm{OH} ; \mathrm{R}_{2}=\mathrm{OCH}_{3}\right)$

2 Bellidifolin-8-O-glucoside (Swertianolin) $\left(\mathrm{R}_{1}=\mathrm{R}_{3}=\mathrm{OH} ; \mathrm{R}_{4}=\mathrm{O}\right.$-glucosyl; $\left.\mathrm{R}_{2}=\mathrm{OCH}_{3}\right)$

Roots/Aerial

Roots

$1,3,7,8-$ substitution

Roots / Aerial<smiles>[R]c1cc([R2])c2c(=O)c3c(O)c([R])ccc3oc2c1</smiles>

3 Norswertianin

Roots/Aerial

$\left(\mathrm{R}_{1}=\mathrm{R}_{2}=\mathrm{R}_{3}=\mathrm{OH}\right)$

4 Norswertianin-1,3-diglucoside $\left(\mathrm{R}_{2}=\mathrm{OH} ; \mathrm{R}_{1}=\mathrm{R}_{3}=\mathrm{O}\right.$-diglucosyl $)$

5 Decussatin $\left(\mathrm{R}_{1}=\mathrm{R}_{2}=\mathrm{R}_{3}=\mathrm{OCH}_{3}\right)$ Plant part Roots/Aerial

Roots / Aerial

$\left(\mathrm{R}_{1}=\mathrm{O}\right.$-primverosyl; $\left.\mathrm{R}_{4}=\mathrm{OH} ; \mathrm{R}_{2}=\mathrm{R}_{3}=\mathrm{OCH}_{3}\right)$

5 Bellidifolin- 8-O-glucoside (Swertianolin) $\left(\mathrm{R}_{1}=\mathrm{R}_{3}=\mathrm{OH} ; \mathrm{R}_{4}=\mathrm{O}\right.$-glucosyl; $\left.\mathrm{R}_{2}=\mathrm{OCH}_{3}\right)$

$1,3,7,8-$ substitution<smiles>[Z2]c1cc([R2])c2c(=O)c3c(O)c([R6])ccc3oc2c1</smiles>

6 Isoswertianin $\left(\mathrm{R}_{1}=\mathrm{R}_{2}=\mathrm{OH} ; \mathrm{R}_{3}=\mathrm{OCH}_{3}\right)$

7 Methylswertianin Roots $\left(\mathrm{R}_{1}=\mathrm{OH} ; \mathrm{R}_{2}=\mathrm{R}_{3}=\mathrm{OCH}_{3}\right)$

Roots

Methylswertianin-1-O-gentiobioside

Roots

$\left(\mathrm{R}_{1}=\mathrm{O}\right.$-gentiobiosyl; $\left.\mathrm{R}_{2}=\mathrm{R}_{3}=\mathrm{OCH}_{3}\right)$

9 Norswertianin-1-O-glucoside $\left(\mathrm{R}_{1}=\mathrm{O}\right.$-glucosyl; $\left.\mathrm{R}_{2}=\mathrm{R}_{3}=\mathrm{OH}\right)$

Roots

principles responsible for the in vitro antiglioma action of ether and methanolic extracts of the plant (Isaković et al., 2008). The assessment of structure-activity relationship in a series of structurally related xanthones from G. kochiana and Gentianella austriaca revealed dihydroxylation at positions 7,8 of the xanthone nucleus as the key structural feature responsible for the ability to induce microtubule-associated G2/Mcell block and apoptotic cell death in glioma cells (Isaković et al., 2008).

\subsection{The comparative study on Gentianella albanica, $G$ crispata and G. austriaca}

Methanol extracts of the aerial parts of three Gentianella species, G. albanica, G. crispata, and G. austriaca, were analyzed by reversed-phase HPLC with photodiode array detection (HPLC/DAD). The chromatograms indicated considerable similarity between the investigated species, revealing almost the same constituents (Figure 16). All species were characterized by the presence of three classes of compounds typical for Gentianaceae, such as secoiridoids, C-glucoflavones and xanthones (Janković, 2005). The main isolated and identified compounds were: demethylbellidofolin, bellidifolin, corymbiferin, demethylbellifolin-8-O-glucoside, bellidifolin-8-O-glucoside,
corymbifertin-1-O-glucoside, veratriloside, lanceoside, swertisin, campestroside, mangiferin and isoorientin. The chromatogram of G. austriaca was presented as a representative example for thorough chemical analyses (Figure 17, Table 13). The main comparative characteristics for G. crispata and Balkan endemic species G. albanica are given in Tables 14 and 15.

The G. austriaca aerial part has the same profile as G. albanica, having one more compound, campestroside (Figure 17). The roots of these three investigated Gentianella species contained the same xanthone profile, except again for campestroside, and flavonoids, but the content of secoiridoids was detected to be higher in G. austriaca. The presence of veratriloside and lanceoside were confirmed for the genus Gentianella for the first time (Table 13). Demethylbellidifolin, bellidifolin as well as their 8-O-glycosides were recognized as the carrier of pharmacological effects. Demethylbellidifolin, demethylbellidifolin-8$O$-glucoside, bellidifolin-8-O-glucoside, and swertisin exhibited radioprotective effect; bellidifolin and demethylbellidifolin possess cardioprotective properties, while bellidifolin, bellidifolin-8-O-glucoside, swertizin, and isoorientin, besides antioxidant properties showed significant hypoglycemic activity. Overall, xanthones are recognized as hepatoprotective, hypolipidemic, anticholinesterase, and cerebral vasodilator agents (Jiang et al., 2021; Tchamo Diderot et al., 2006).

Recently, a pharmacological study (Janković et al., 2008) involving radioprotective effects of G. austriaca ether and methanolic fractions and polyphenolic constituents (demethylbellidifolin and its 8-O-glucoside, as well as bellidifolin-8-Oglucoside and swertisin) in human lymphocytes was under- 
Table 8. Gentiana kochiana botanical data

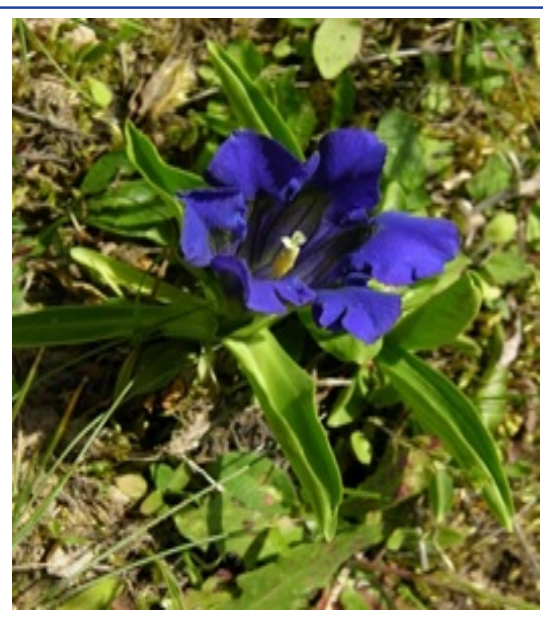

Gentiana acaulis L., common name: velemun

syn. G. kochiana E.P.Perrier \& Songeon

\section{General distribution}

Iberian and Balkan Peninsula, Alps and Carpathians, Central European Mountains

\section{Floral element}

Central and southern Europe

\section{Habitat}

Mountain ores with acid silicate substrate, mostly southern exposures

\section{Distribution in the Central Balkans}

Serbia: Kopaonik, Golija, Stara planina

Macedonia: Pelister, Karadzic

Montenegro: Bjelasica, Visitor, Chakor, Hajla

\section{Taxonomic status}

Section: Megalanthe

Aggregate: G. acaulis L.
Table 9. Gentiana dinarica botanical data

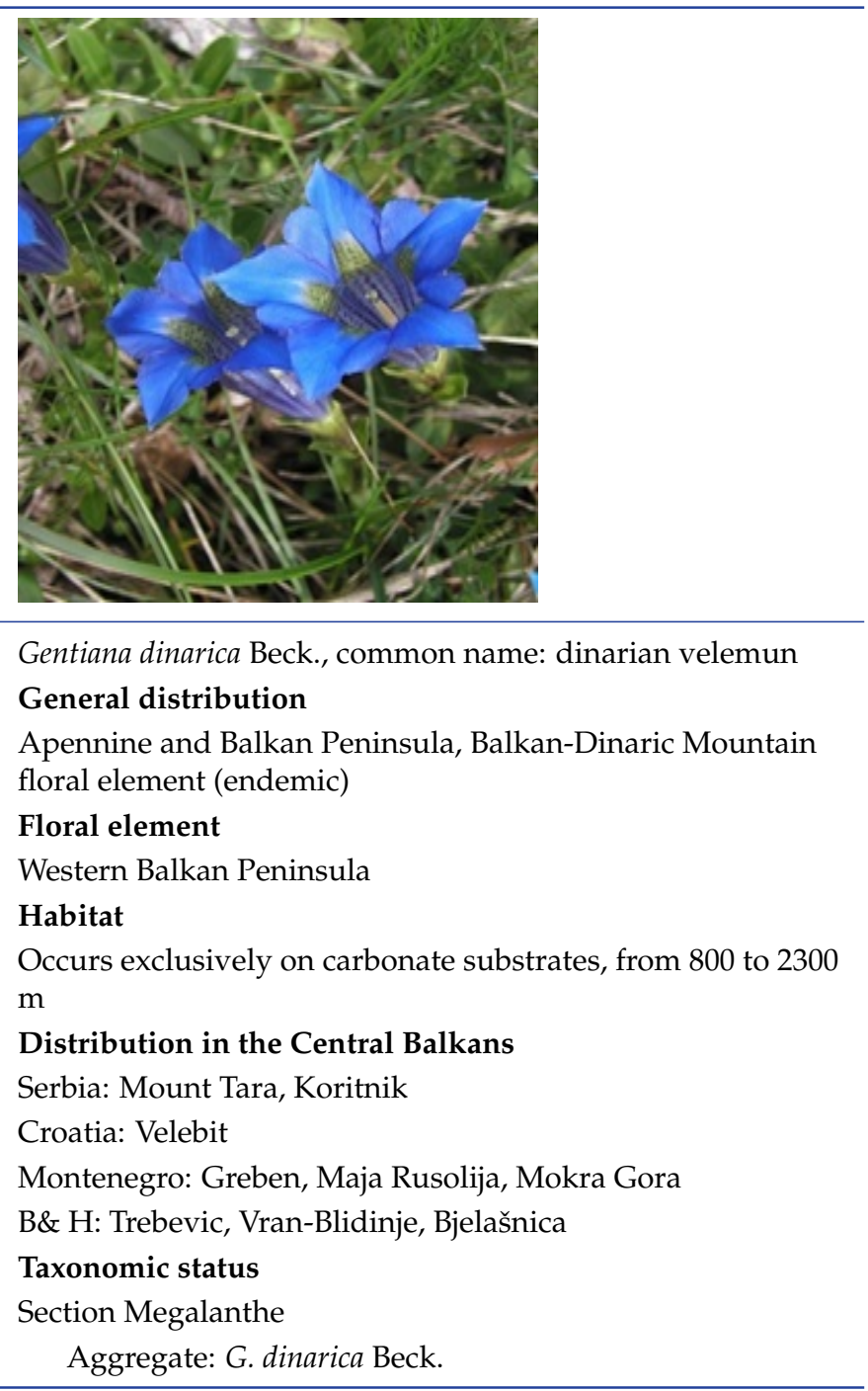

Table 10. Chemical profile of the species G. kochiana ment of human lymphocytes after $\gamma$-irradiation than isolated compounds. These results suggested that the antioxidative properties of polyphenols tested might be responsible for contributing to the radioprotective effects of G. austriaca.

Interestingly, in the Chinese province of Mongolia, the herb "guixincao", G. acuta (Michaux.) Hulten, Gentianaceae (Figure 18) has been used as a medicinal tea, for colds, to cleanse the blood of harmful substances and pathogens. Besides, it has been known for its diuretic effect. This species has a very similar xanthone profile as our investigated G. austriaca, with demethylbellidifoline and bellidifoline and their corresponding heterosides as dominant constituents. This plant exhibits various biological activities such as: antioxidant, antiinflammatory, antibacterial, hypoglycemic, antitumor, cardioprotective (Ren et al., 2019). Contrary, in European traditional medicine there is no data that G. austriaca was used.

\subsection{The comparative study on Anthemis carpatica and $A$. montana}

Sesquiterpene lactones (SLs), one of the most prevalent groups of the secondary metabolites in the Asteraceae family, are known for their antimicrobial, antitumoral, and antiinflammatory activities, effects on the central nervous and cardiovascular systems as well as allergenic potency. One of the most attractive properties that SLs possess, is their antiinflammatory potential. Inflammation represents a patho-

\begin{tabular}{|c|c|c|}
\hline & $1,3,7,8$ - substitution & \\
\hline & $\prod_{0} \int_{\mathrm{R}_{4}} 8$ & \\
\hline 1 & $\begin{array}{l}\text { Gentiakochianin } \\
\left(\mathrm{R}_{1}=\mathrm{R}_{3}=\mathrm{R}_{4}=\mathrm{OH} ; \mathrm{R}_{2}=\mathrm{OCH}_{3}\right)\end{array}$ & Aerial \\
\hline 2 & $\begin{array}{l}\text { Gentiokochianin-7-primveroside } \\
\left(\mathrm{R}_{1}=\mathrm{R}_{4}=\mathrm{OH} ; \mathrm{R}_{3}=\mathrm{O} \text {-primverosyl; } \mathrm{R}_{2}=\mathrm{OCH}_{3}\right)\end{array}$ & Roots/Aerial \\
\hline 3 & $\begin{array}{l}\text { Gentiacaulein } \\
\left(\mathrm{R}_{1}=\mathrm{R}_{3}=\mathrm{OH} ; \mathrm{R}_{2}=\mathrm{R}_{4}=\mathrm{OCH}_{3}\right)\end{array}$ & Roots/Aerial \\
\hline 4 & $\begin{array}{l}\text { Gentiacaulein-1-primveroside } \\
\left(\mathrm{R}_{1}=\mathrm{O} \text {-primvesrosyl; } \mathrm{R}_{2}=\mathrm{R}_{4}=\mathrm{OCH}_{3} ; \mathrm{R}_{3}=\mathrm{OH}\right)\end{array}$ & Roots/Aerial \\
\hline 5 & $\begin{array}{l}\text { Gentiacaulein-1-glycoside } \\
\left(\mathrm{R}_{1}=\mathrm{O} \text {-glucosyl; } \mathrm{R}_{2}=\mathrm{R}_{4}=\mathrm{OCH}_{3} ; \mathrm{R}_{3}=\mathrm{OH}\right)\end{array}$ & Roots/Aerial \\
\hline 6 & $\begin{array}{l}\text { Decussatin } \\
\left(\mathrm{R}_{1}=\mathrm{OH} ; \mathrm{R}_{2}=\mathrm{R}_{3}=\mathrm{R}_{4}=\mathrm{OCH}_{3}\right)\end{array}$ & Aerial \\
\hline 7 & $\begin{array}{l}\text { Decussatin-1-primveroside } \\
\left(\mathrm{R}_{1}=\mathrm{O} \text {-primverosyl; } \mathrm{R}_{2}=\mathrm{R}_{3}=\mathrm{R}_{4}=\mathrm{OCH}_{3}\right)\end{array}$ & Roots/Aerial \\
\hline
\end{tabular}



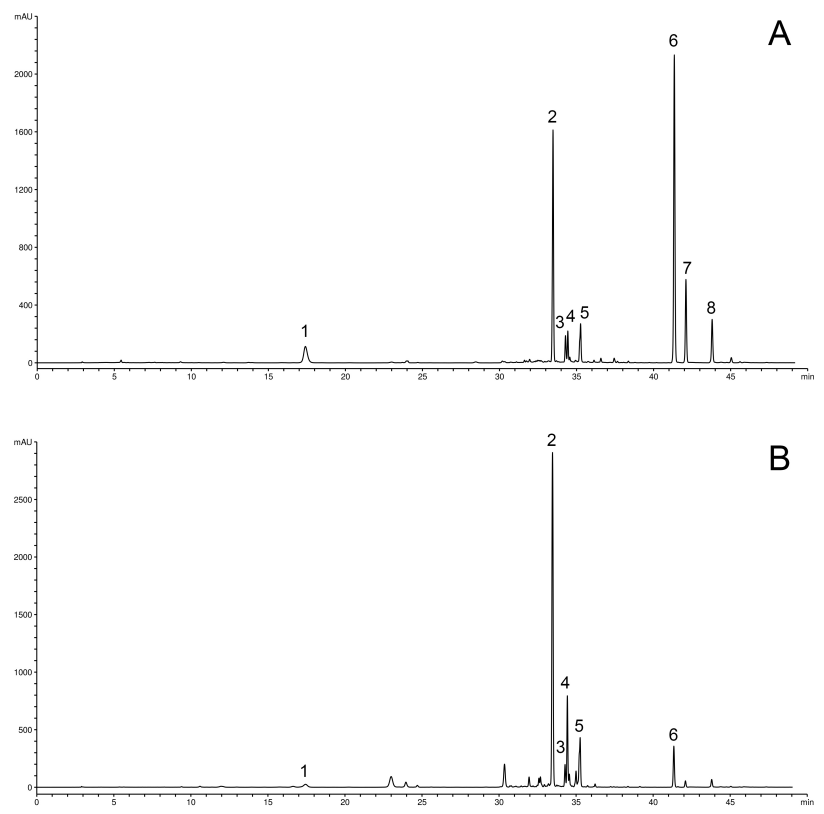

$B$

Fig. 13. HPLC chromatogram of Gentiana kochiana extracts; A aerial parts; B - roots; 1, secoiridoid derivative; 2, gentiacaulein1-O-primveroside; 3 , gentiacaulein-1-O-glucosyl, 4, decussatin-1-Oprimveroside; 5, 1,8-dihydroxy-3-metoxy-7-O-primveroside; - 6, gentiacaulein; 7 , gentiakochianin; 8 , decussatin
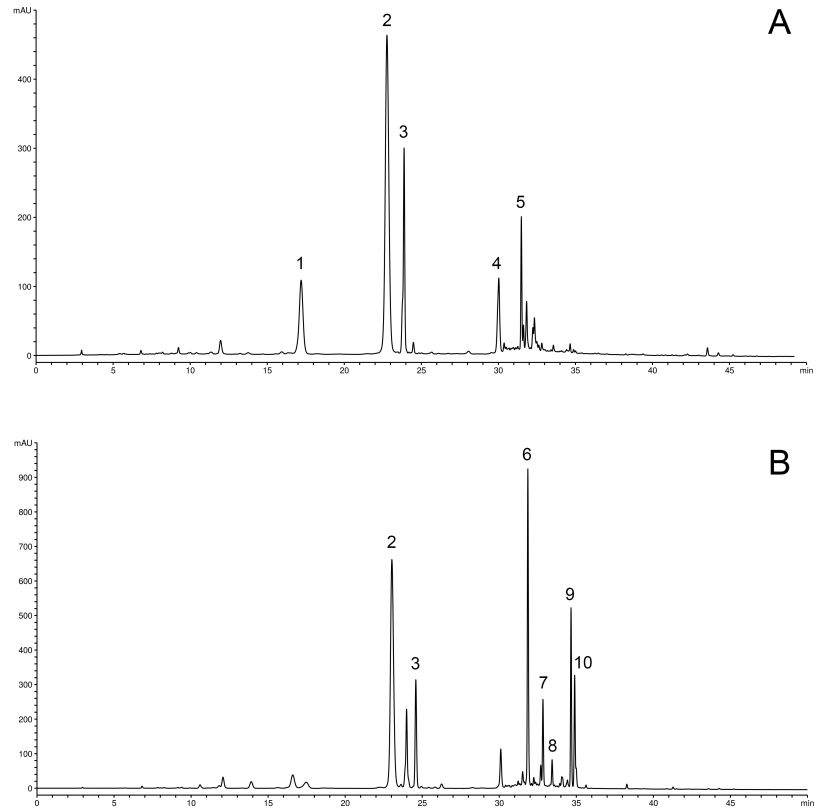

Fig. 14. HPLC chromatogram of Gentiana dinarica extracts; A - aerial parts; B - roots; 1, swertiamarin; 2, gentiopicrin; 3, isoorientin4'-O-glycoside; 4, isoorientin; 5, isovitexin; 6, norswertianin-1-Oprimveroside; 7 , norswertianin-8-O-primveroside; 8, norswertianin-1O-glucoside; 9 , gentioside; 10 , amarogentin (secoiridoid)

Table 11. Chemical profile of the species G. dinarica

Table 12. C-flavonoids detected in aerial part of $G$. dinarica

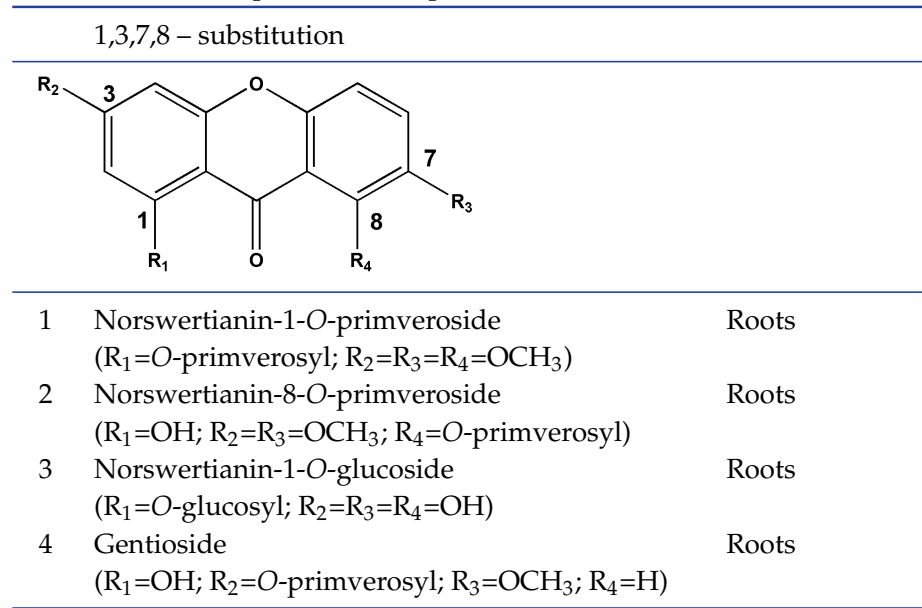
$1,3,7,8-$ substitution<smiles>[R]c1ccc(-c2cc(=O)c3c([R])c([R])c([R])cc3o2)cc1[R]</smiles>

1 Isoorientin-4'-O-glucoside $\left(\mathrm{R}_{1}=\mathrm{R}_{3}=\mathrm{R}_{4}=\mathrm{OH} ; \mathrm{R}_{2}=\right.$ glucosyl $\mathrm{R}_{5}=\mathrm{O}$-glucosyl $)$ $\left(\mathrm{R}_{1}=\mathrm{R}_{3}=\mathrm{R}_{4}=\mathrm{R}_{5}=\mathrm{OH} ; \mathrm{R}_{2}=\right.$ glucosyl $)$

3 Isovitexine $\left(\mathrm{R}_{1}=\mathrm{R}_{3}=\mathrm{R}_{5}=\mathrm{OH} ; \mathrm{R}_{2}=\right.$ glucosyl; $\left.\mathrm{R}_{8}=\mathrm{H}\right)$
2 Isoorientine
Aerial

Aerial

Aerial physiological process, comprising the integrated response of many defense systems of the body to the invasion of a foreign body of any kind. The great interest in inflammation is due to the involvement of its components in many serious diseases, including cancer, Alzheimer's disease, and acquired immunodeficiency syndrome (AIDS). The anti-inflammatory mechanisms include inhibition of the production of cytokines, lipid mediators, and other related molecules, modulation of pro- and antioxidant contents, and regulation of intracellular signaling pathways. These mechanisms are involved in several inflammatory diseases; thus, determining the chemical structure of the SLs that could reduce and/or help to control inflammatory diseases and their symptoms might properly direct the investigation for novel compounds with the desired pharmacological properties. In addition, the chemotaxonomic importance of SLs, together with various mentioned biological activities, is the major reason for the continuing interest in these compounds.

In order to perform the necessary chemotaxonomic and pharmacological inquires, the structure elucidation of pure and isolated SLs should be carried out. Figure 19 represents the schematic display of simple methodologies used for isolation and purification of SLs present in the investigated aerial part of Anthemis carpatica Willd. and A. montana L., Asteraceae. The investigation had been carried out at the Faculty of Chemistry, University of Belgrade, under Prof. Slobodan Milosavljevic supervision (Bulatović et al., 1998). The applied extraction and purification techniques yielded thirty-one SLs of the same guaiadienolide type, all of them exhibiting an exomethylene 11(13) double bond, and one of germacranolide type (Figures $20,21)$. According to proven chemotaxonomic importance and various biological activities, structure elucidation plays an important role in all of the studies concerning this class of 

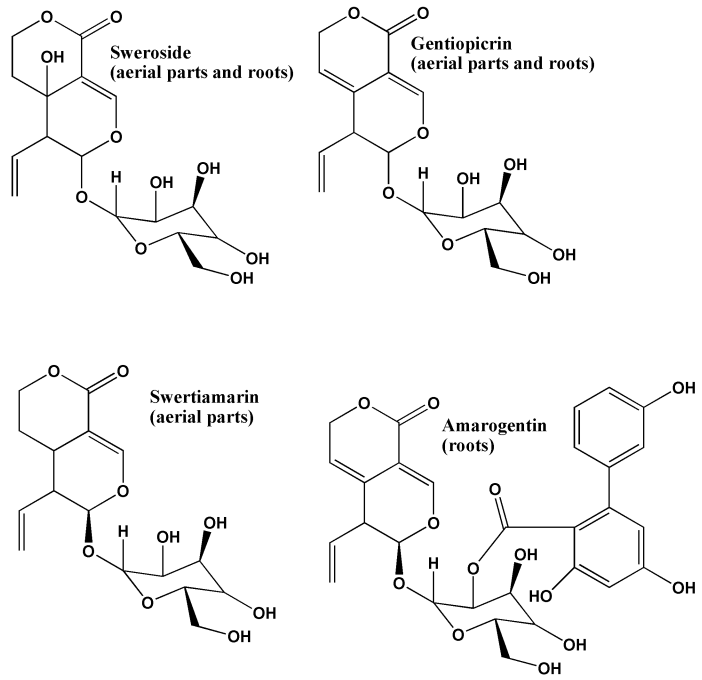

Fig. 15. Secoiridoids detected in aerial part of $G$. dinarica

Table 13. The structures of the main identified $\gamma$-pyrone compounds in aerial parts of $G$. austriaca

\begin{tabular}{ll} 
\\
\hline
\end{tabular}

\footnotetext{
7 Veratriloside

$\left(\mathrm{R}_{3}=\mathrm{R}_{4}=\mathrm{CH}_{3} ; \mathrm{R}_{7}=\right.$ glucosyl $\left.; \mathrm{R}_{8}=\mathrm{H}\right)$
}

8 Lanceoside

Aerial

$\left(\mathrm{R}_{3}=\mathrm{R}_{7}=\mathrm{CH}_{3} ; \mathrm{R}_{4}=\right.$ glucosyl $\left.; \mathrm{R}_{8}=\mathrm{OH}\right)$

Aerial

Fig. 16. Comparative fingerprint chromatograms of aerial parts of G. crispata, G. albanica and G. austriaca

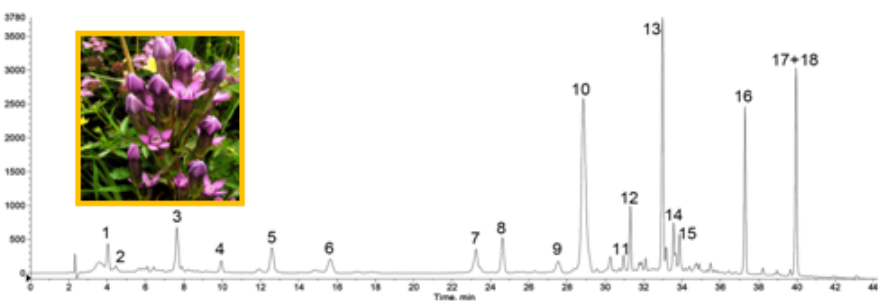

Fig. 17. "Fingerprint" chromatogram of G. austriaca (A. \& J. Kern.) Holub, Gentianaceae; 1, eustomorussid; 2, eustomosid; 3, campestroside isomer; 4, loganic acid; 5, swertiamarin; 6, gentiopicrin; 7, mangiferin; 8, campestroside; 9 , lanicerin; 10, demethylbellidifolin8-O-glucoside; 11, isovitexin; 12, swertisin; 13, bellidifolin-8-Oglucoside; 14, corymbiferin-1-O-glucoside; $\mathbf{1 5}$, veratriloside; 16 demethylbellidifolin; 17, bellidifolin; $\mathbf{1 8}$, corymbiferin

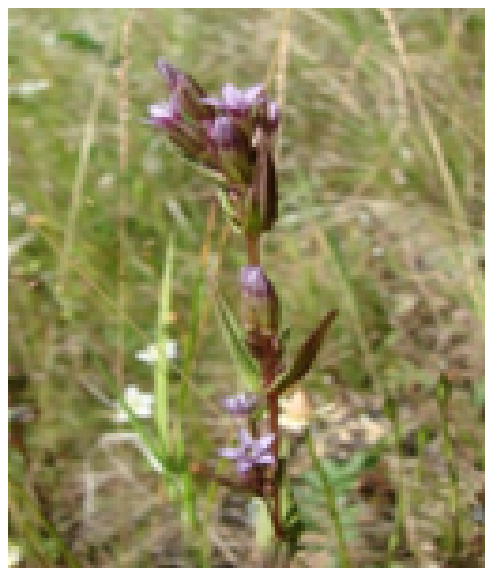

Fig. 18. Gentianella acuta (Michaux.) Hulten Gentianaceae

that several phases may be delineated, such as a) determination of the enzymatic steps leading to the common precursors of the metabolic pathway; b) the use of molecular biology to probe the changes in gene expression associated with the compounds. In the characterization of the chemical structures of the isolated natural compounds, Dixon (2005) proposed 
Table 14. Gentianella albanica botanical data

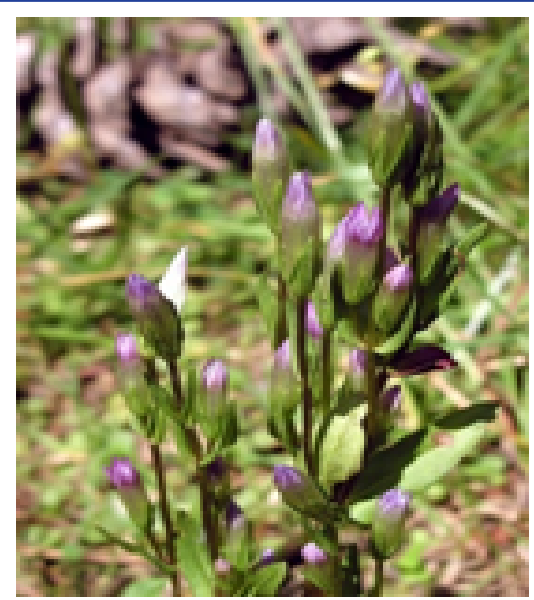

Gentianella albanica (Jáv.) Holub

General distribution

Central Balkans (Albania, Montenegro, Serbia)

Geological background

Carbonate

\section{Habitat}

Elevation: 2300 - $2530 \mathrm{~m}$ above sea level

Alpine carbonate ores Oxytpodion dinaricae (Elyno-Edraianthetum alpini, Elyno-Leontopodietum Rudski)

\section{Floral element}

Central Balkan mountain endemic

Distribution in the Central Balkans

Montenegro - Komovi, Prokletije (Maja Karanfili, Hajla,

Žljeb).

\section{Taxonomic status}

Section: Gentanella

Gentianella albanica (Jáv.) Holub

plasticity of natural products metabolism; c) the emergence of functional genomics, providing a more accurate picture of the diversity of the genes/enzymes involved in the metabolism of secondary metabolites; d) the exploitation of genetic engineering for optimizing the secondary metabolites profiles in plants; e) the employment of pharmacological and clinical studies supporting the traditional application of plants.

Increased interest in the study of natural products as potential drugs and rapidly changing research strategies have been potentiating the role of pharmacognosy in the wider context of pharmaceutical research. To present the usefulness of combined pharmacognostic and chemistry approaches to medicinal plant investigations, here, we will present the research performed on two Anthemis species, similar in their habitat but different in chemical components belonging to SLs. Applying different sophisticated techniques for the identification of the unknown isolated compounds from plant material, interesting results had been obtained. Generally, the most widely used method is NMR spectroscopy. ${ }^{1} \mathrm{H}$ NMR spectral data analysis is usually starting point since it is one of the most informative techniques for this purpose. The ${ }^{1} \mathrm{H}$ NMR analyses of purified SLs from $A$. carpatica and $A$. montana extract revealed the existence of three types of guaianolides, marked as $\Delta^{2}, \Delta^{3}$, and $\Delta^{4}$-group, depending on the position of a double bond in a five-membered, non-lactone ring (Figure 23).

Application of the sophisticated two-dimensional nuclear magnetic resonance (2D NMR) methods, including some new vari-
Table 15. Gentianella crispata botanical data

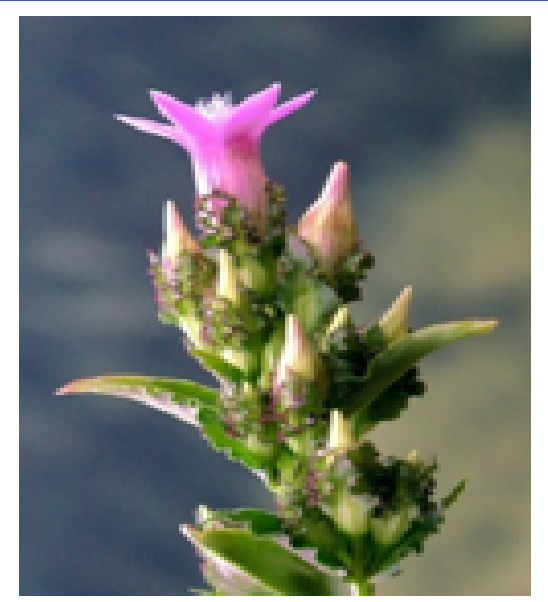

Gentianella crispata (Vis.) Holub

\section{General distribution}

Balkan Peninsula - Bulgaria, Albania, Montenegro, Dalmatia, Bosnia and Herzegovina.

\section{Habitat}

Dry and poor habitats (pastures and meadows) in the Alpine region

\section{Floral element}

It belongs to the Pontic-Balkan floral element

Distribution in the Central Balkans

Serbia: Kosovo and Metohija

Taxonomic status

Section: Gentanella

Gentianella crispata (Vis.) Holub

ations of the known techniques (e.g., ${ }^{13} \mathrm{C}$ NMR spectra editing using Heteronuclear Single Quantum Correlation) in combination with other spectrometric methods (e.g. chemical ionization mass spectrometry), demonstrated the power of structure-guided screening as a complementary method to assay-guided screening, enabling complete structural assignment and determination of relative stereochemistry of natural products. Such an approach enables the possibility to determine the novel rather than known plant constituents. ${ }^{1} \mathrm{H}$ and ${ }^{13} \mathrm{C}$ NMR assignment and structure determination of both major and minor components of isolated SLs were based on the characteristic chemical shifts and couplings obtained by the first-order analysis combined with 2D NMR measurements, such as Double Quantum Filtered Correlated Spectroscopy (DQF COSY), Total Correlated Spectroscopy (TOCSY), Nuclear Overhauser Effect Spectroscopy (NOESY), HSQC (Heteronuclear Single Quantum Correlation) and HMBC (Heteronuclear Multiple Band Correlation) performed on isolated compounds. Thus, this combination of high-performance separations techniques with structurally informative spectroscopic methods (MS and NMR) could allow extracts to be screened not just for biologically active compounds, but at the same time for chemically significant structural classes (Bulatović et al., 1998; Da Costa et al., 2004; Djordjević et al., 2004; Juranić et al., 1998; Milosavljević et al., 1999b; 2004; 1998; Schmidt, 1996; Yoshioka, 1974).

To demonstrate the importance of employing the abovementioned methods in complete structure elucidation of the isolate SLs, special attention was paid to lactone belonging to $\Delta^{2}$-group of isolated lactones, lactone 5 (8-O-isobutyryl- 
9-O-acetylanthemolide B). It was studied utilizing 2D NMR methods (DQF COSY, TOCSY, NOESY, HSQC, and HMBC). Although the application of COSY method enabled the identification of $8 \alpha, 9 \alpha$-diacyloxyguaia-2,11(13)-dienolide gross structure (Figure 24), and the presence of tertiary $\mathrm{OH}$ and $\mathrm{OOH}$ groups, the TOCSY, NOESY, and HMBC spectra were necessary to determine the acylation pattern, as well to establish unambiguously the position of tertiary C- 4 and C- 10 oxygen functions. In the case of lactone 18 (Figure 25), the application of the mentioned 2D NMR methods revealed the existence of two conformers. Namely, in addition to employing the first-rate NMR analyses, the DQF COSY (Figure 25A), as well as ${ }^{13} \mathrm{C}$ data measured in HSQC (Figure 25B) enabled the identification of compound 18 as $9 \alpha$-acetoxycumambrin A. As the previously used scalar $\mathrm{H}, \mathrm{H}$-coupling networks measurements revealed the interesting conformational exchange present in 18, the HSQC and COSY analyses performed at the low-temperature regime, gave the evidence of the existence of two conformers - the distorted chair conformation of 7 -membered ring in lactones $18 \mathrm{~A}$ and $18 \mathrm{~B}$, with (pseudo)axial and (pseudo)equatorial $10 \beta$-methyl, respectively.

\section{STUDIES ON MONTENEGRIN ENDEMIC TANACE- TUM LARVATUM USING ${ }^{1} \mathrm{H}$ NMR FOR PARTHENO- LIDE QUANTIFICATION}

Plants from the genus Tanacetum L. (Asteraceae) have been used in traditional medicine from ancient times, of which Tanacetum parthenium (L.) Shultz-Bip. (feverfew) has been known as a remedy for the treatment of various diseases, including migraine, arthritis, fever, vertigo, menstrual disorders, stomachache, and psoriasis (Ernst and Pittler, 2000; Wider et al., 2015). Additionally, T. vulgare L. (common tansy) and T. microphyllum DC. are useful in the treatment of various inflammatory disorders (Silván et al., 1998; Zhang et al., 2005). A recent investigation of $T$. larvatum extract suggested the application of this species as an alternative or supplementary herbal remedy for the treatment of inflammatory diseases due to its anti-inflammatory and anti-ulcer activities (Petrović et al., 2003). The secondary metabolites that mediate these pharmacological effects are mainly biologically active sesquiterpene lactones, such as parthenolide and hydroxyachillin. Parthenolide, found in significant amounts in feverfew, has been indirectly linked to the anti-migraine action of feverfew preparations, as well as to anti-tumor and anti-inflammatory properties (Wen et al., 2002). The mode of parthenolide activity comprises the inhibition of prostaglandin production and 5-hydroxytryptamine secretion as mediators of inflammation (Kang et al., 2001; Mittra et al., 2000). A recent investigation confirmed its gastric anti-ulcer properties due to its ability to restore the reduction of sulfhydryl groups within the gastric mucosa and to increase mucosal PGE2 level (Ernst and Pittler, 2000; Wider et al., 2015).

Because of the assumed importance of parthenolide content for pharmacological activities, supported by the studies already performed, hence, we investigated the parthenolide content in T. larvatum (Gris.) Kanitz., Asteraceae, endemic species originated from Sinjajevina, Montenegro (Josifović, 1975; Pantocsek, 1873). The collected material was subjected to quantitative ${ }^{1} \mathrm{H}$ NMR and HPLC analysis (Figure 26). Bearing in mind that $T$. parthenium native to Serbia does not contain parthenolide, of chemotaxonomic importance are the intriguing results concerning the parthenolide content and antioxidant activity of T. larvatum, which were comparable, even higher, than those of T. parthenium. The present data support further investigation of this species as a new commercial source of parthenolide or potential herbal remedy with an- timigraine, anti-inflammatory, and gastroprotective effects (Aljančić et al., 2010; 2001; Bulatović et al., 2006; Tadić et al., 2010).

\section{CONCLUSIONS}

By modernizing and renewing the proven science, pharmacognosy represents the strategic connection between biology and chemistry. This multidisciplinary approach in the discovery of novel and unique molecules with the biological potential to target specific impairments in human organisms is necessary. On the other hand, the chemical composition of plants represents the specific characteristics that might be used for the investigated plant to ascertain the specific place in plants systematics. The classification of plants according to their chemical constitution is defined as chemotaxonomy. Namely, various dilemmas regarding the correct systematic classification of plants have been solved by performing the chemotaxonomic analysis. A wide variety of studies include the chemotaxonomic classification of secondary metabolites; among the most investigated compounds being xanthones and sesquiterpene lactones. In this review, the importance of employing the combined chemical and pharmacognostic approach to the investigation of Montenegrin flora, with emphasis on endemic species was stressed. The chemotaxonomic dilemma regarding the systematic classification of Swertia perennis, Gentiana kochiana and G. dinarica, as well as Gentainella albanica and G. austriaca, might be solved by applying the chemical approach. In addition, the structure-activity investigation enables the recognition of the pattern that might be successfully used to classify a set of str-

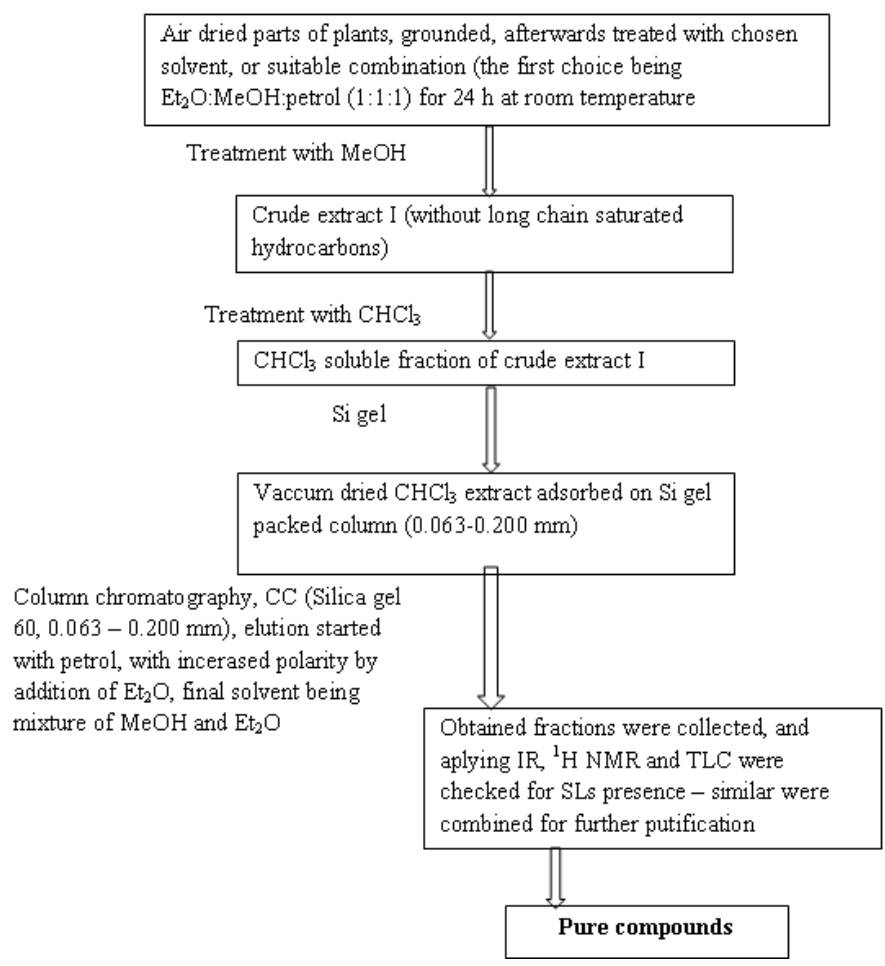

Fig. 19. The schematic presentation of the isolation and purification of identified sesquiterpene lactones from $A$. carpatica and $A$. montana 


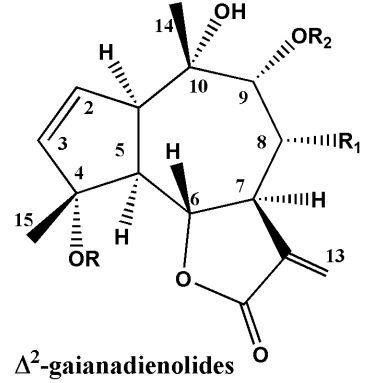

\begin{tabular}{lccc} 
& $\mathbf{R}$ & $\mathbf{R}_{1}$ & $\mathbf{R}_{2}$ \\
\hline $\mathbf{1}^{\mathbf{c}}$ & $\mathbf{H}$ & $\mathbf{H}$ & $\mathbf{A c}$ \\
$\mathbf{2}^{\mathbf{c}, \mathbf{m}}$ & $\mathbf{O H}$ & $\mathbf{O A c}$ & $\mathbf{H}$ \\
$\mathbf{3}^{\mathbf{c}}$ & $\mathbf{O H}$ & $\mathbf{O H}$ & $\mathbf{A c}$ \\
$\mathbf{4}^{\mathbf{c}, \mathbf{m}}$ & $\mathbf{O H}$ & $\mathbf{O A c}$ & $\mathbf{A c}$ \\
$\mathbf{5}^{\mathbf{c}, \mathbf{m}}$ & $\mathbf{O H}$ & $\mathbf{O}-\boldsymbol{i}$-But & $\mathbf{A c}$ \\
$\mathbf{6}^{\mathbf{c}}$ & $\mathbf{H}$ & $\mathbf{O}-\boldsymbol{i}-\mathbf{B u t}$ & $\mathbf{A c}$ \\
$7^{\mathbf{c}}$ & $\mathbf{O H}$ & $\mathbf{H}$ & $\mathbf{A c}$ \\
$\mathbf{8}^{\mathbf{c}, \mathbf{m}}$ & $\mathbf{O H}$ & $\mathbf{O H}$ & $\mathbf{H}$ \\
$\mathbf{9}^{\mathbf{c}}$ & $\mathbf{O H}$ & $\mathbf{O T i g}$ & $\mathbf{A c}$ \\
$\mathbf{1 0}^{\mathbf{m}}$ & $\mathbf{O H}$ & $\mathbf{O A n g}$ & $\mathbf{A c}$
\end{tabular}

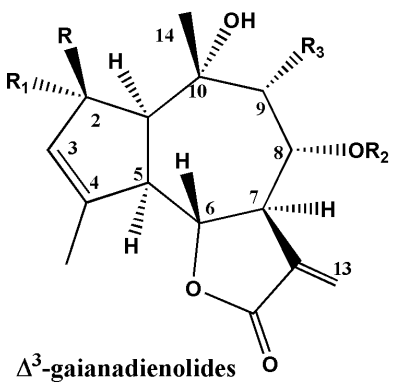

\begin{tabular}{|c|c|c|c|c|}
\hline & $\mathbf{R}$ & $\mathbf{R}_{1}$ & $\mathbf{R}_{2}$ & $\mathbf{R}_{3}$ \\
\hline $11^{\mathrm{c}, \mathrm{m}}$ & H & $\mathbf{H}$ & H & OAc \\
\hline $12^{\mathrm{c}, \mathrm{m}}$ & $\mathbf{H}$ & H & Ac & OH \\
\hline $13^{c}$ & H & $\mathbf{H}$ & Ac & OAc \\
\hline $14^{\mathrm{c}}$ & H & OOH & $i$-But & OAc \\
\hline $15^{\mathrm{c}}$ & H & H & H & $\mathbf{H}$ \\
\hline $16^{\mathrm{c}}$ & $\mathbf{O H}$ & $\mathbf{H}$ & H & $\mathbf{H}$ \\
\hline $17^{\mathrm{c}}$ & H & $\mathbf{H}$ & $i$-But & OAc \\
\hline $18^{\mathrm{m}}$ & OAc & H & $i$-But & $\mathbf{O A c}$ \\
\hline $19^{\mathrm{m}}$ & OAc & $\mathbf{H}$ & $\mathbf{H}$ & OAc \\
\hline $20^{\mathrm{m}}$ & OAc & H & Ac & OAc \\
\hline $21^{\mathrm{m}}$ & OAc & $\mathbf{H}$ & H & O-i-But \\
\hline $22^{\mathrm{m}}$ & OAc & H & H & $0-i$-Val \\
\hline $23^{\mathrm{m}}$ & OAc & $\mathbf{H}$ & $\mathbf{H}$ & O-2-MeBu \\
\hline
\end{tabular}

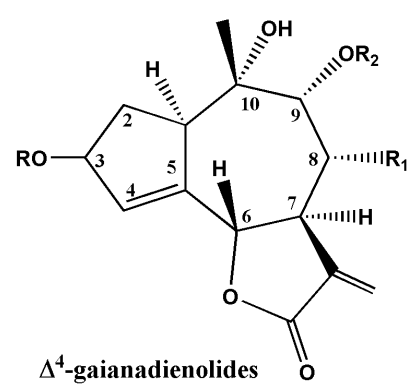

\begin{tabular}{lccc} 
& $\mathbf{R}$ & $\mathbf{R}_{1}$ & $\mathbf{R}_{2}$ \\
\hline $24^{\mathbf{c}}$ & $\mathbf{H}$ & $\mathbf{H}$ & $\mathbf{A c}$ \\
$25^{\mathbf{c}, \mathbf{m}}$ & $\mathbf{H}$ & OAc & Ac \\
$26^{\mathbf{c}}$ & $\mathbf{O H}$ & OAc & Ac \\
$27^{\mathbf{c}}$ & $\mathbf{H}$ & OAc & H \\
$28^{\mathbf{c}}$ & $\mathbf{H}$ & OProp & Ac \\
$29^{\mathbf{c}}$ & $\mathbf{H}$ & O- $i$-But & Ac \\
$30^{\mathbf{c}}$ & $\mathbf{H}$ & OTig & Ac \\
$31^{\mathbf{c}}$ & OH & O-i-But & Ac
\end{tabular}

Fig. 20. Sesquiterpenoids isolated from two Anthemis sp.; c sesquiterpenes isolated from $A$. carpatica, $\mathrm{m}$ - sesquiterpene isolated $A$. cretica subsp. cretica c,m - sesquiterpene isolated from both investigated species

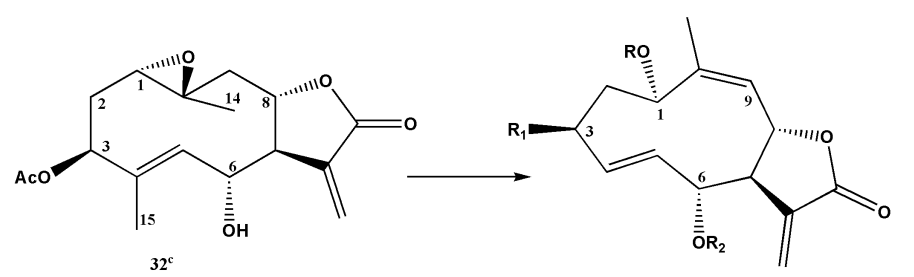

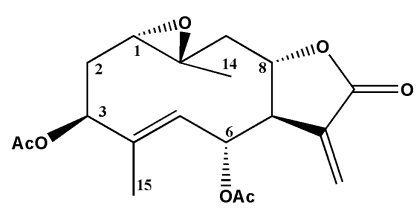

\begin{tabular}{lrcc} 
& $\mathbf{R}$ & $\mathbf{R}_{1}$ & $\mathbf{R}_{2}$ \\
\hline $33^{\mathrm{c}}$ & $\mathbf{H}$ & $\mathbf{O A c}$ & $\mathbf{H}$ \\
$34^{\mathrm{c}}$ & $\mathbf{A c}$ & $\mathbf{O A c}$ & $\mathbf{A c}$ \\
$35^{\mathrm{c}}$ & $\mathbf{H}$ & $\mathbf{H}$ & $\mathbf{A c}$ \\
$36^{\mathrm{c}}$ & $\mathbf{H}$ & $\mathbf{H}$ & $\mathbf{A c}$
\end{tabular}
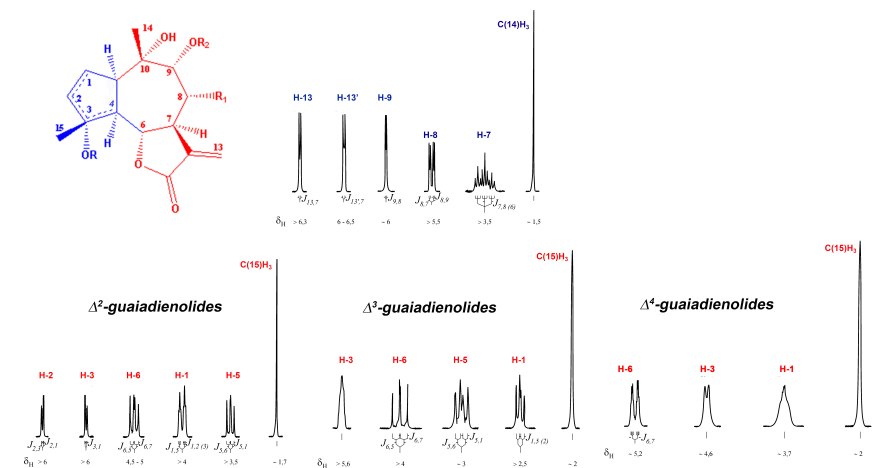

Fig. 23. Characteristic chemical shifts in ${ }^{1} \mathrm{H}\left(\mathrm{C}_{5} \mathrm{D}_{5} \mathrm{~N}\right) \mathrm{NMR}$ spectra and couplings assigned to SLs isolated from $A$. carpatica and $A$. montana; red highlight in the guaiadienolides structure common for isolated SLs; blue common for $\Delta^{2}$-lactones, $\Delta^{3}$-lactones; and $\Delta^{4}$ lactones

Fig. 21. New germacranolides isolated from A. carpatica 

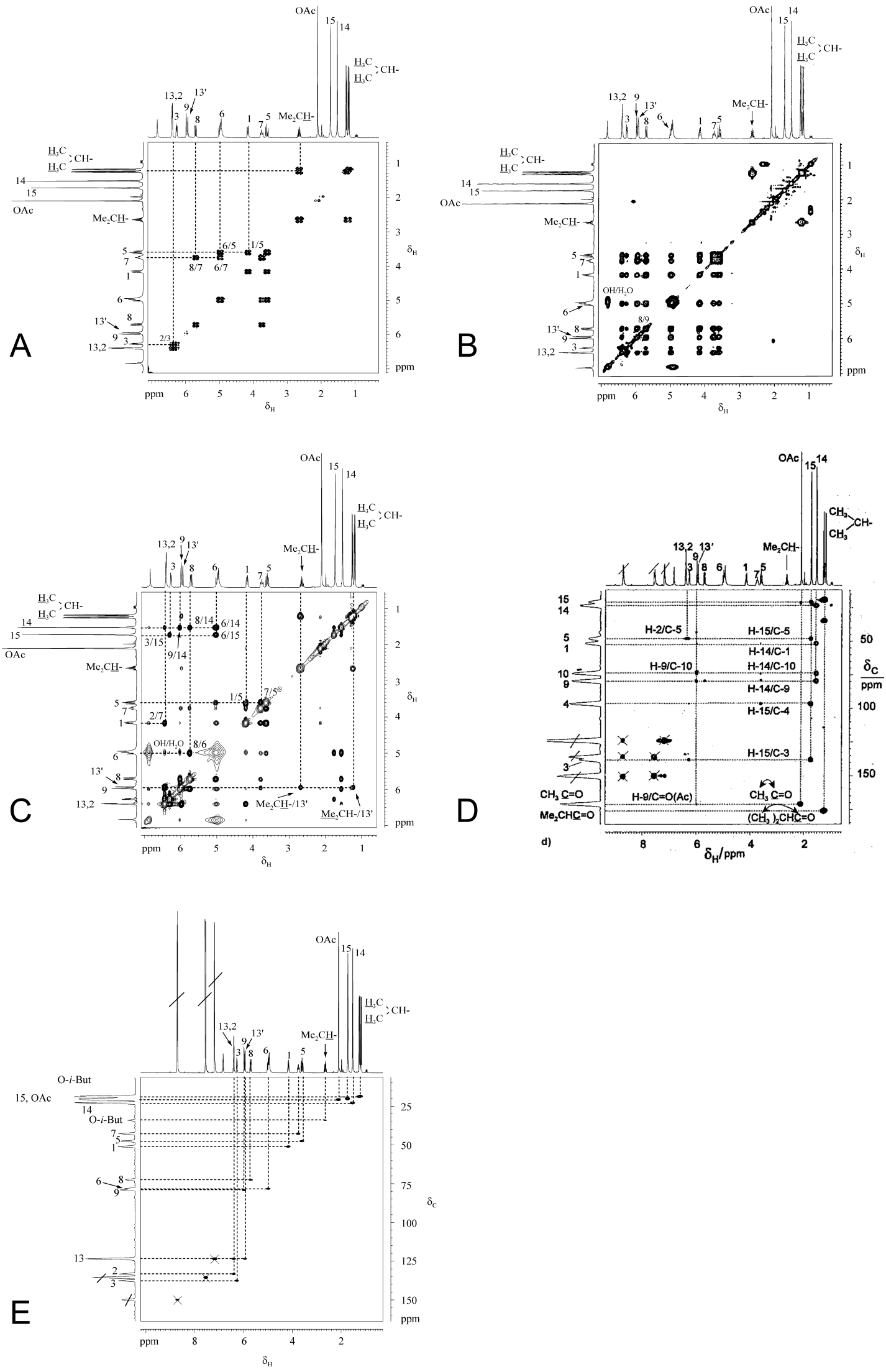

Fig. 24. Structure elucidation of lactone 5 : A, DQF COSY (in $\mathrm{C}_{5} \mathrm{D}_{5} \mathrm{~N}$ ); B, TOCSY spectrum in $\mathrm{C}_{5} \mathrm{D}_{5} \mathrm{~N}$; correlation due to a chemical exchange $\mathrm{OOH} / \mathrm{OH}$ not shown; $\mathrm{C}$, NOESY spectrum in $\mathrm{C}_{5} \mathrm{D}_{5} \mathrm{~N}$; D, Long-range heteronuclear $\mathrm{C}, \mathrm{H}$-correlation (HMBC) spectrum in $\mathrm{C}_{5} \mathrm{D}_{5} \mathrm{~N}$; $\mathrm{E}$, One bond heteronuclear $\mathrm{C}, \mathrm{H}$-correlation (HSQC) spectrum in $\mathrm{C}_{5} \mathrm{D}_{5} \mathrm{~N}$ 

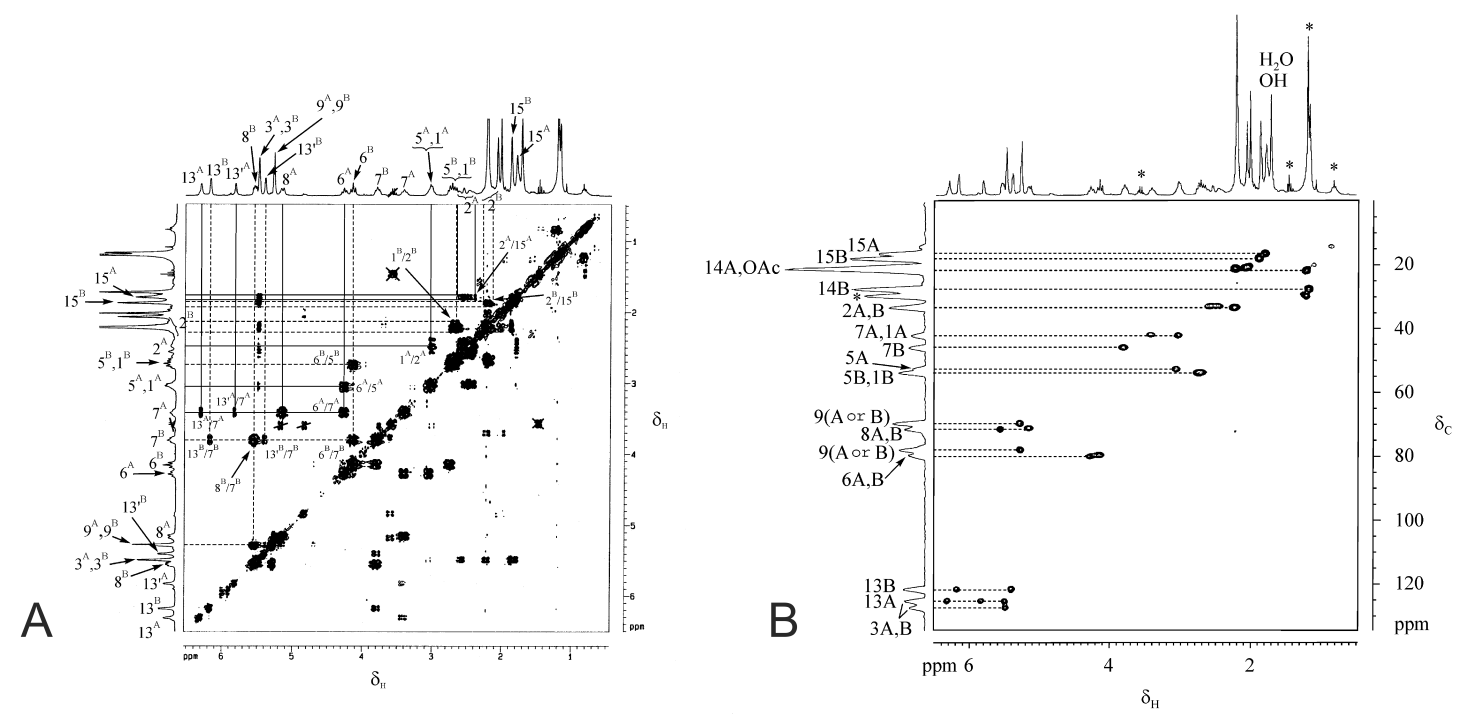

Fig. 25. DQF COSY (A) and HSQC (B) of lactone 18 in $\mathrm{CDCl}_{3}$ at $-30{ }^{\circ} \mathrm{C}$
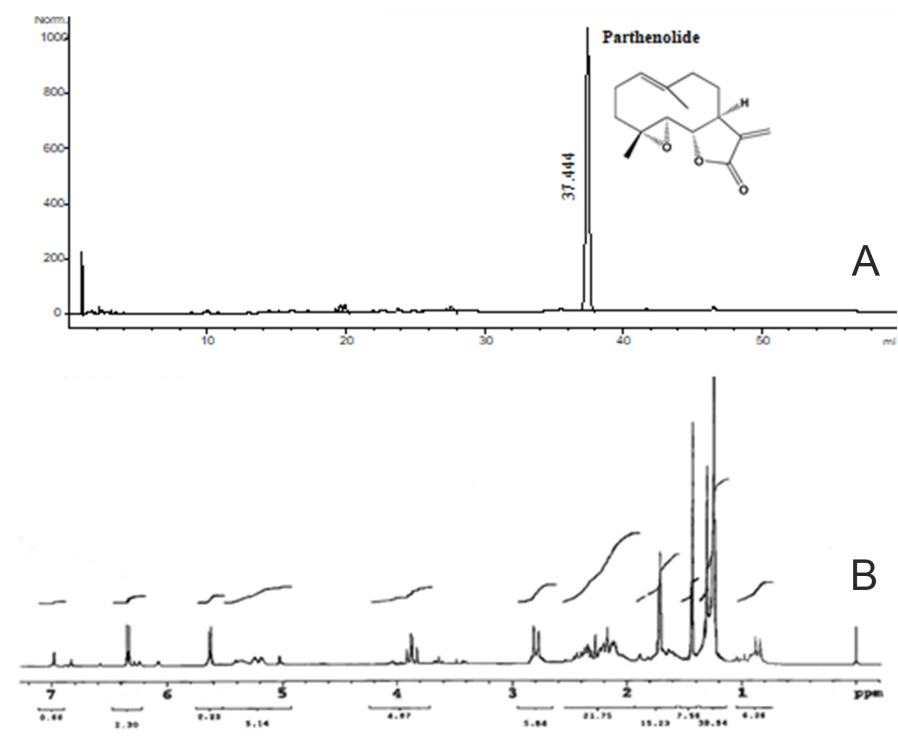

Fig. 26. The HPLC (A) and ${ }^{1} \mathrm{H}-\mathrm{NMR}$ (B) fingerprint profile of T. larvatum extract from Mountain Sinjajevina, Montenegro 
ucturally diverse compounds as therapeutic agents. Taking into account the numerous activities that sesquiterpenes possess, thorough determination of their presence in some $A n-$ themis species plants was reviewed, as well. The investigation of the Montenegrin endemic species, T. larvatum revealed that this species is rich in parthenolide, a secondary metabolite known for its antimigraine activity. The application of simple ${ }^{1} \mathrm{H}$ NMR techniques in quantification studies of parthenolide content was reviewed. The presented investigation gave an insight into the usefulness of these integrated pharmacognostic and chemical approaches in the investigation of natural products that originated from plants.

\section{FUNDING}

The authors wish to send their gratitude to the Serbian Ministry of Education, Science and Technological Development (Contract No. 451-03-9/2021-14/ 200003).

\section{REFERENCES}

Aljančić, I. S., Vajs, V. E., Milosavljević, S. M., Todorović, N., Menković, N. R., Gođevac, D. and Tadić, V. M. (2010). Comparative analysis of parthenolide content in Tanacetum larvatum, an endemic species of Montenegro, collected from three different locations, Chemistry of Natural Compounds 46(4): 658-660.

Aljančić, I., Vajs, V., Bulatović, V., Menković, N. and Milosavljević, S. (2001). Parthenolide from the aerial parts of Tanacetum larvatum, Biochemical Systematics and Ecology 29(6): 655-657.

Aljančić, I., Vajs, V., Tešević, V. and Milosavljević, S. (2008). Some wildgrowing plant species from Serbia and Montenegro as the potential sources of drugs, Current Pharmaceutical Design 14(29): 3089-3105.

Šavikin, K., Aljančić, I. S., Vajs, V. E., Milosavljević, S. M., Jadranin, M., Đorđević, I. and Menković, N. R. (2015). Bioactive secondary metabolites in several genera of Gentianaceae species from the central regions of the Balkan Peninsula, in J. J. Rybczyński, M. R. Davey and A. Mikuła (eds), The Gentianaceae - Volume 2: Biotechnology and Applications, Springer Berlin Heidelberg, Berlin, Heidelberg, pp. 319347.

Balijagić, J., Markisić, H., Jovančević, M., Praščević, M., Vincek, D. and Menković, N. (2011). Contribution to the research of medicinal and other plants in the mountainous region of Čakor, Montenegro, Agriculture \& Forestry 57(3): 67-92.

Braun-Blanquet, J. (1964). Pflanzensoziologie, Springer Vienna, Vienna.

Bulatović, V. M., Menković, N. R., Vajs, V. E., Milosavijević, S. M. and Đoković, D. D. (1997a). Essential oil of Anthemis carpatica, Journal of Essential Oil Research 9(4): 397-400.

Bulatović, V. M., Menković, N. R., Vajs, V. E., Milosavljević, S. M. and Đoković, D. D. (1998). Essential oil of Anthemis montana, Journal of Essential Oil Research 10(2): 223-226.

Bulatović, V. M., Vajs, V., Aljancić, I. T., Milosavljević, S., Đoković, D. D. and Petrović, S. (2006). Chemical composition of Tanacetum larvatum essential oil, Journal of Essential Oil Research 18(2): 126-128.

Bulatović, V., Vajs, V., Macura, S., Juranić, N. and Milosavljević, S. (1997b). Highly oxygenated guaianolides from Anthemis carpatica, Journal of Natural Products 60(12): 1222-1228.

Da Costa, F. B., Binev, Y., Gasteiger, J. and Aires-de Sousa, J. (2004). Structure-based predictions of ${ }^{1} \mathrm{H}$ NMR chemical shifts of sesquiterpene lactones using neural networks, Tetrahedron Letters 45(37): 69316935.

Dahlgren, R. M. T. (1980). A revised system of classification of the angiosperms, Botanical Journal of the Linnean Society 80(2): 91-124.

Dixon, R. A. (2005). Engineering of plant natural product pathways, Current Opinion in Plant Biology 8(3): 329-336.

Djordjević, I., Vajs, V., Bulatović, V., Menković, N., Tešević, V., Macura, S., Janaćković, P. and Milosavljević, S. (2004). Guaianolides from two subspecies of Amphoricarpos neumayeri from Montenegro, Phytochemistry 65(16): 2337-2345.

Ernst, E. and Pittler, M. (2000). The efficacy and safety of feverfew ( Tanacetum parthenium L.): an update of a systematic review, Public Health Nutrition 3(4a): 509-514.

Godjevac, D., Vajs, V., Menkovic, N., Tesevic, V., Janackovic, P. and Milosavljevic, S. (2004). Flavonoids from flowers of Cephalaria pas- tricenis and their antiradical activity, Journal of the Serbian Chemical Society 69(11): 883-886.

Gođevac, D., Mandić, B., Vajs, V., Menković, N., Macura, S. and Milosavljević, S. (2006a). Complete assignments of ${ }^{1} \mathrm{H}$ and ${ }^{13} \mathrm{C}$ NMR spectra of leucanthoside A, a new triterpenoid saponin from Cephalaria leucantha L., Magnetic Resonance in Chemistry 44(7): 731-735.

Gođevac, D., Mandić, B., Vajs, V., Tešević, V., Menković, N., Janaćković, P. and Milosavljević, S. (2006b). Triterpenoid saponins and iridoid glycosides from the aerial parts of Cephalaria pastricensis, Biochemical Systematics and Ecology 34(12): 890-893.

Gorunović, M. and Lukić, P. (2001). Farmakognozija, Naša knjiga, Beograd.

Hostettmann, K. and Wagner, H. (1977). Xanthone glycosides, Phytochemistry 16(7): 821-829.

Isaković, A., Janković, T., Harhaji, L., Kostić-Rajačić, S., Nikolić, Z., Vajs, V. and Trajković, V. (2008). Antiglioma action of xanthones from Gentiana kochiana: Mechanistic and structure-activity requirements, Bioorganic \& Medicinal Chemistry 16(10): 5683-5694.

Janković, T. (2005). Comparative study of chemical constituents of Gentianella plant species, Ph.D. Thesis, Faculty of Chemistry, University of Belgrade, Serbia.

Janković, T., Šavikin, K., Menković, N., Aljančić, I., Leskovac, A., Petrović S. and Joksić, G. (2008). Radioprotective effects of Gentianella austriaca fractions and polyphenolic constituents in human lymphocytes, Planta Medica 74(07): 736-740.

Janković, T., Krstić, D., Aljančić, I., Šavikin Fodulović, K., Menković, N., Vajs, V. and Milosavljević, S. (2005). Xanthones and C-glucosides from the aerial parts of four species of Gentianella from Serbia and Montenegro, Biochemical Systematics and Ecology 33(7): 729-735.

Janković, T., Krstić-Milošević, D., Aljančić, I., Šavikin, K., Menković, N., Radanović, D. and Milosavljević, S. (2009). Phytochemical re-investigation of Gentiana utriculosa, Natural Product Research 23(5): 466-469.

Janković, T., Vinterhalter, B., Krstić-Milošević, D., Nikolić, R., Vinterhalter, D. and Milosavljević, S. (2011). Xanthone compounds in shoot cultures of Gentianella bulgarica, Acta Physiologiae Plantarum 33(4): 15151520.

Jiang, M., Cui, B.-W., Wu, Y.-L., Nan, J.-X. and Lian, L.-H. (2021). Genus Gentiana: A review on phytochemistry, pharmacology and molecular mechanism, Journal of Ethnopharmacology 264: 113391.

Josifović, M. (ed.) (1975). Flora of Republic of Serbia, Vol. VII, Serbian Academy of Sciences and Art, Belgrade. [in Serbian].

Jovanović-Dunjić, R. (1973). Swertia L., in M. Josifović (ed.), Flore de la Republique Socialiste de Serbie, Serbian Academy of Science and Arts, pp. 407-408.

Juranić, N., Zolnai, Z. and Macura, S. (1998). Elucidation of deceptively slow magnetization exchange between protein labile protons and water by dilution-enhanced exchange spectroscopy, Journal of the American Chemical Society 120(38): 9963-9964.

Kang, B., Chung, S. and Kim, T. (2001). Inhibition of interleukin-12 production in lipopolysaccharide-activated mouse macrophages by parthenolide, a predominant sesquiterpene lactone in Tanacetum parthenium: involvement of nuclear factor- $\kappa \mathrm{B}$, Immunology Letters 77(3): 159-163.

Krstić, D., Janković, T., Aljančić, I., Šavikin Fodulović, K., Menković, N. and Milosavljević, S. (2004). Phytochemical investigation of Gentiana dinarica, Biochemical Systematics and Ecology 32(10): 937-941.

Krstić-Milošević, D. (2008). Chemical investigation of pharmacologically active secondary metabolites of some species from genus Gentiana, Ph.D. Thesis, Faculty of Chemistry, University of Belgrade.

Lakušić, R. (1968). Planinska vegetacija jugoistočnih Dinarida, Glasnik republičkog Zavoda za zaštitu prirode i prirodnjačke zbirke, Titograd 1: 9-75. [in Serbian].

Lakušić, R. (1971). Istorija proučavanja biljnog svijeta na području Prokletija, Komova i Bjelasice, Tokovi, Ivangrad. [in Serbian].

Lakušić, R. (1974). Specifičnosti flore i vegetacije Komova i Prokletija, Tokovi, Ivangrad. [in Serbian].

Lakušić, R. (1990). Planinske biljke, Svjetlost, Zavod za udžbenike i nastavna sredstva, Sarajevo - Zavod za udžbenike i nastavna sredstva, Beograd. [in Serbian].

Lakušić, R. and Milojević, M. (1972). Ljekovito bilje na planinama Prokletija, Komova i Bjelasice, Tokovi, Ivangrad.

Lakušić, R., Vučković, M. and Markišić, H. (1985). Specifičnosti Prokletija. Prokletije - zaštita i unapređivanje plavskog dijela Prokletija., Republički Zavod za Zaštitu Prirode, Titograd. [in Serbian]. 
Lukić, P. (1985). Farmakognozija, 3 edn, Farmaceutski fakultet, Univerzitet u Beogradu, Beograd. [in Serbian].

Menković, N., Šavikin Fodulović, K., Bulatović, V., Aljančić, I., Juranić, N., Macura, S., Vajs, V. and Milosavljević, S. (2002). Xanthones from Swertia punctata, Phytochemistry 61(4): 415-420.

Menković, N., Šavikin, K., Tasić, S., Zdunić, G., Stešević, D., Milosavljević S. and Vincek, D. (2011). Ethnobotanical study on traditional uses of wild medicinal plants in Prokletije Mountains (Montenegro), Journal of Ethnopharmacology 133(1): 97-107.

Menković, N., Šavikin, K., Zdunić, G., Milosavljević, S. and Živković, J. (2014). Medicinal plants in Northern Montenegro: Traditional knowledge, quality, and resources, in A. Pieroni and C. L. Quave (eds) Ethnobotany and Biocultural Diversities in the Balkans, Springer New York, New York, NY, pp. 197-228.

Milojević, B., Mihajlov, M. and Tucakov, J. . (1974). Uporedno određivanje arbutozida u vrstama rodova Arctostaphylos Adans. (ericaceaae) i Vaccinium Lindl (Vacciniaceae) s područja Prokletija i Komova, Tokovi, Ivangrad 9: 161-174.

Milosavljević, S., Bulatović, V. and Stefanović, M. (1999b). Sesquiterpene lactones from the Yugoslavian wild growing plant families Asteraceae and Apiaceae, Journal of the Serbian Chemical Society 64(7-8): 397442.

Milosavljević, S., Juranić, I., Bulatović, V., Macura, S., Juranić, N., Limbach, H.-H., Weisz, K., Vajs, V. and Todorović, N. (2004). Conformational analysis of guaianolide-type sesquiterpene lactones by lowtemperature NMR spectroscopy and semiempirical calculations, Structural Chemistry 15(3): 237-245.

Milosavljević, S., Vajs, V., Bulatović, V., Đoković, D., Aljančić, I., Juranić N. and Macura, S. (1999a). ChemInform abstract: Application of two-dimensional nuclear magnetic resonance methods for structure elucidation of sesquiterpene lactones (guaianolides) from Anthemis carpatica and diterpenes (kauranes) from Achillea clypeolata, ChemInform 30(45).

Milosavljević, S., Vajs, V., Bulatović, V., Đoković, D., Aljančić, I., N., J. and Macura, S. (1998). Application of two-dimensional nuclear magnetic resonance methods for structure elucidation of sesquiterpene lactones (guaianolides) from Anthemis carpatica and diterpenes (kauranes) from Achillea clypeolata, Recent Research Development in Phytochemistry 2: 383-395.

Mittra, S., Datta, A., Singh, S. and Singh, A. (2000). 5-hydroxytryptamineinhibiting property of feverfew: role of parthenolide content, Acta Pharmacologica Sinica 21(12): 1106-1114.

Niaz, K. and Khan, F. (2020). Analysis of polyphenolics, Recent Advances in Natural Products Analysis, Elsevier, pp. 39-197.

Pančić, J. (1874). Flora kneževine Srbije ili vaskularne biljke, koje y Srbije divlie rastu - Flora Principatus Serbiae, Štampa Državne Štamparije, Beograd.

Pant, N., Jain, D. C. and Bhakuni, R. S. (2000). Phytochemicals from genus Swertia and their biological activities, Indonesian Journal of Chemistry 39B: 565-586.

Pantocsek, J. (1873). Plantae novae quas aestate anni 1872 per Hercegovinam et Montenegro collexit et descripsit, Oesterreichische Botanische Zeitschrift 23(9): 265-268.

Petrović, S. D., Dobrić, S., Bokonjić, D., Niketić, M., Garcia-Piñeres A. and Merfort, I. (2003). Evaluation of Tanacetum larvatum for an anti-inflammatory activity and for the protection against indomethacin-induced ulcerogenesis in rats, Journal of Ethnopharmacology 87(1): 109-113.

Pulević, V. (2005). Građa za vaskularnu floru Crne Gore, Republički zavod za zaštitu prirode Crne Gore, Podgorica.

Pulević, V. (2006). Botaničari i Crna Gora, Prirodnjački muzej Crne Gore, Podgorica. [editor Vizi Ondrej].

Ren, K., Su, H., Lv, L.-j., Yi, L.-t., Gong, X., Dang, L.-s., Zhang, R.-f. and Li, M.-h. (2019). Effects of four compounds from Gentianella acuta (Michx.) Hulten on hydrogen peroxide-induced injury in $\mathrm{H} 9 \mathrm{c} 2$ cells, BioMed Research International 2019: 1-9.

Šavikin-Fodulović, K., Aljančić, I., Vajs, V., Menković, N., Macura, S. Gojgić, G. and Milosavljević, S. (2003). Hyperatomarin, an antibacterial prenylated phloroglucinol from Hypericum atomarium ssp. degenii, Journal of Natural Products 66(9): 1236-1238.

Šavikin, K., Janković, T., Krstić-Milošević, D., Menković, N. and Milosavljević, S. (2010). Secondary metabolites and biological activities of some Gentianaceae species from Serbia and Montenegro, in V. K. Gupta and S. C. Taneja (eds), Comprehensive Bioactive Natural Products
Extraction, Isolation \& Characterization, Studium Press LLC, USA.

Schilcher, H., Kammerer, S. and Wegener, T. (2007). Leitfaden Phytotherapie, Munchen Jena Elsevier, Urban \& Fischer.

Schmidt, T. J. (1996). Helenanolide type sesquiterpene lactones Part 1. Conformations and molecular dynamics of helenalin, its esters and 11,13-dihydro derivatives, Journal of Molecular Structure 385(2): 99112

Šilić, Č. (1983). Šumske zeljaste biljke, Svjetlost, Sarajevo.

Šilić, Č. (1984). Endemične biljke, Svjetlost, Sarajevo.

Silván, A., Abad, M., Bermejo, P. and Villar, A. (1998). Effects of compounds extracted from Tanacetum microphyllum on arachidonic acid metabolism in cellular systems, Planta Medica 64(03): 200-203.

Stevanović, V. (ed.) (1999). Red Book of Flora of Serbia, Ministry for the Protection of Natural Resources and the Environment, Faculty of Biology, University of Belgrade, Belgrade.

Stevanović, V. and Vasić, V. (eds) (1995). Biodiverzitet Jugoslavije sa pregledom vrsta od međunarodnog značaja, Faculty of Biology, University of Belgrade, Ecolibri, Belgrade;.

Tadić, V., Dobrić, S., Marković, G. and Bojović, D. (2009). Analysis of natural products - sesquiterpene lactones as anti-inflammatory agents, in R. Injac, K. Karljikovic and B. Štrukelj (eds), The analysis of pharmacologically active compounds and biomolecules in real samples, Transworld Research Network, Kerala, India, pp. 97-128.

Tadić, V. M., Aljančić, I. S., Vajs, V. E., Milosavljević, S. M., Đoković, D. and Đordjević, I. (2010). Intraspecific variation of Tanacetum larvatum essential oil, Journal of Essential Oil Research 22(5): 394-398.

Tan, K. and Vladimirov, V. (2001). Swertia punctata Baurng. (Gentianaceae) in Bulgaria, Bocconea 13: 461-466.

Tasić, S., Šavikin, K. and Menković, N. (2009). A guide through the world of medicinal herbs, Alexandria, Belgrade.

Tchamo Diderot, N., Silvere, N. and Etienne, T. (2006). Xanthones as therapeutic agents: chemistry and pharmacology, Advances in Phytomedicine, Vol. 2, Elsevier, pp. 273-298.

Tešević, V., Milosavljević, S., Vajs, V., Janaćković, P., Đordjevic, I., Jadranin, M. and Vučković, I. (2007). Quantitative analysis of sesquiterpene lactone cnicin in seven Centaurea species wild-growing in Serbia and Montenegro using ${ }^{1} \mathrm{H}-\mathrm{NMR}$ spectroscopy, Journal of the Serbian Chemical Society 72(12): 1275-1280.

Tomić, M., Tovilović, G., Butorović, B., Krstić, D., Janković, T., Aljančić, I. and Menković, N. (2005). Neuropharmacological evaluation of diethylether extract and xanthones of Gentiana kochiana, Pharmacology Biochemistry and Behavior 81(3): 535-542.

Tovilović-Kovačevicć, G., Zogović, N. and Krstić-Milošević, D. (2020). Secondary metabolites from endangered Gentiana, Gentianella, Cen taurium, and Swertia species (Gentianaceae): promising natural biotherapeutics, Biodiversity and Biomedicine, Elsevier, pp. 335-384.

Trifunović, S., Vajs, V., Juranić, Z., Žižak, Ž., Tešević, V., Macura, S. and Milosavljević, S. (2006). Cytotoxic constituents of Achillea clavennae from Montenegro, Phytochemistry 67(9): 887-893.

Tucakov, J., Milojević, B. and Mihajlov, M. (1974). Upotreba bilja u narodnoj medicini na području Prokletija i Komova u Crnoj Gori, Tokovi, Ivangrad 9.

Tutin, T., Heywood, V., Burges, N., Moore, D., Valentine, D., Walters, S. and Webb, D. (eds) (1972). Flora Europaea, Cambrige University Press, London.

Vajs, V., Bulatović, V., Fodulović-Šavikin, K., Nebojša Menković, Macura S., Juranić, N. and Milosavljević, S. (1999). Highly oxygenated guaianolides from Anthemis cretica subsp. cretica, Phytochemistry 50(2): 287291.

Vajs, V., Todorović, N., Bulatović, V., Menković, N., Macura, S., Juranić N. and Milosavljević, S. (2000). Further sesquiterpene lactones from Anthemis carpatica, Phytochemistry 54(6): 625-633.

Vuksanović, S. (2016). Distribution, Chorological Structure And Centers Of Diversity Of The Balkan Endemic Flora In Montenegro, Ph.D. Thesis, University of Belgrade, Faculty of Biology, Belgrade.

Wen, J., You, K.-R., Lee, S.-Y., Song, C.-H. and Kim, D.-G. (2002). Oxidative Stress-mediated Apoptosis, Journal of Biological Chemistry 277(41): 38954-38964.

Wider, B., Pittler, M. H. and Ernst, E. (2015). Feverfew for preventing migraine, Cochrane Database of Systematic Reviews 4(4): CD002286.

Yoshioka, H. (ed.) (1974). Sesquiterpene lactones: Chemistry, N.M.R. and plant distribution, University of Tokyo Press.

Zdunić, G. (2012). Comparative chemical analysis and pharmacological profile of extracts of selected species of the genus Hypericum L., Ph.D. 
Thesis, University of Belgrade, Faculty of Pharmacy.

Zdunić, G., Gođevac, D., Šavikin, K., Novaković, M., Milosavljević, S. and

Petrović, S. (2011). Isolation and identification of phenolic compounds from Hypericum richeri Vill. and their antioxidant capacity, Natural Product Research 25(3): 175-187.

Zhang, S., Won, Y.-K., Ong, C.-N. and Shen, H.-M. (2005). Anti-cancer potential of sesquiterpene lactones: Bioactivity and molecular mechanisms, Current Medicinal Chemistry-Anti-Cancer Agents 5(3): 239-249. 